経 営史 学

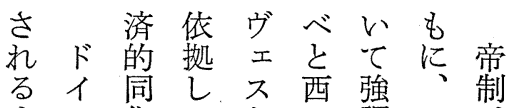

まツ化つトエ調こド

で鉄のつフルされイ

、道ああアべれをツ

さ業りき稖

まに方らレいき位一

ざ対にかンうた鬲。の

ますもにの異。補経

なる 言し 鉄質西充 済

角政度、道的工卞的

度府专資なルる契

かのるわ本社べ政機

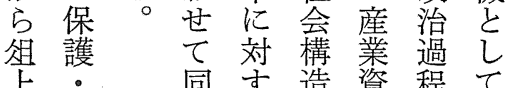

上規 社る同方資程て

の制の介相にプ 商

せと金入互対口品

らい融のにすイ流

机閶過浸る。 通

々題乲梨透 プ国資

り注資交イ家本

は

め

$\sqrt{c}$

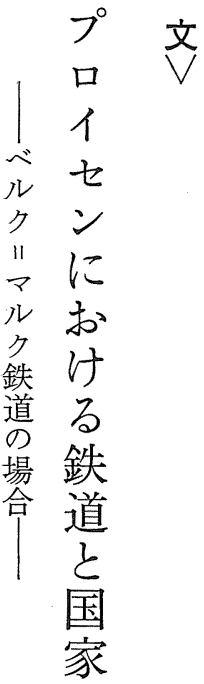

わ、本べたセ権市

けビ 財ルのさカ場

同スのクで政の

時マ調"あ⿱府介労

代ル達マるのの大㗢

人ク先ルら支と兮

のにを、名配以市

政上鉄。力 場

策 察道本の視文

提て 䄅稿行点、

言 プ 会染使㤎ら

と口こ下、注、国

しイ と く

てセに B プいが市

論ンよ $\mathrm{M}$ 口つ国場

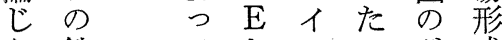

ら鉄てをていだ成

れ道帝略ンどイ要

たが制記国の ツ因

のほ ド家程資吕

でぼイの権度本指

あ完 ツ経力主摘

る全に営ので義さ

に拉内 ラ、研れ

当国け資イ東究る

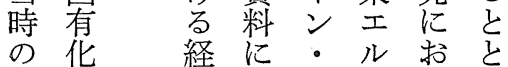

田

徹

雄 


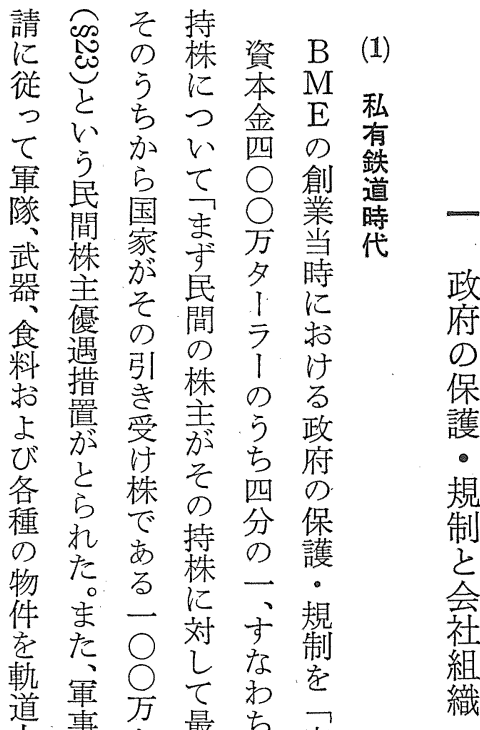

のでと害でに模営 プ 性実しをあ移の私口 格現て、市る 行 小有 イ をた 他し : ‘ 道ン 敷の面て d 大品のの 一衍かで活・き1典鉄

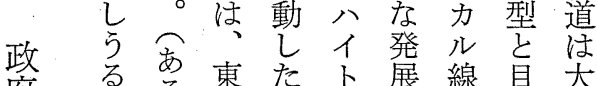

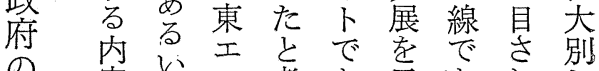
保容はル考あ示あれし

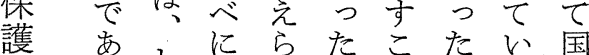
規学充基れて 彼に方る。有

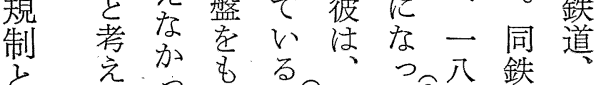

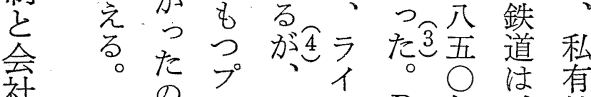
組

の口ーン B 年 鉄

吕イ 面: $\mathrm{M}$ 以 $\mathrm{E}$ 道 う政は、ル の 国プを棠 以府こヨ棠口占私 っの らア 化イッ有 た経しジのセパ鉄 問済た 推ン I道 題担 ラの進政夕に は当イひ者府厂分 ひのンとはのル類 と閣: り 鉄地 禁 り僚ヴと当道域る 八とエし時保のこ イしスて、の護産 京 々てト経務 策業準 公了済大と本き うれ। 政臣ののる 個ぞレ策で連主が 性れンのあ繫導、 をのの分りのの B 越利産野、\& \& $\mathrm{M}$ え害業にしとと E

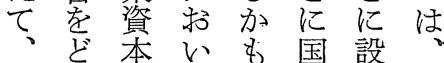
帝ののて 元嫦立こ 制よ利故同私さ の ドう害郷社有れう イな代の役鉄だ ツ 形 表 利員道規 国 
経 営史学

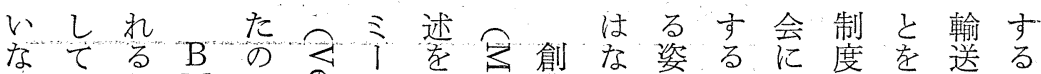

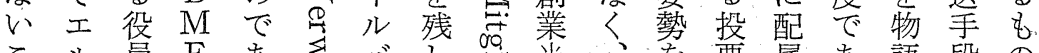

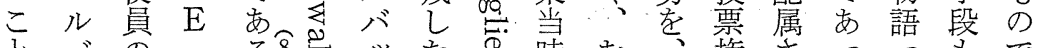

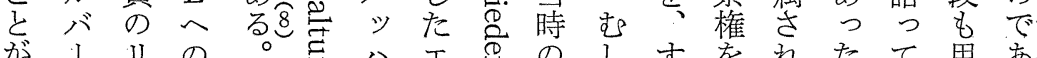
が解フ リ の るエ ス出资 资す

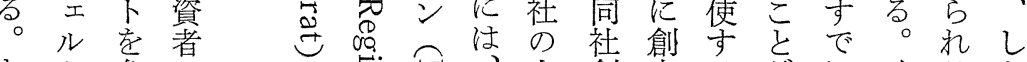

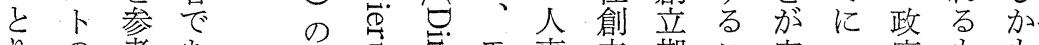

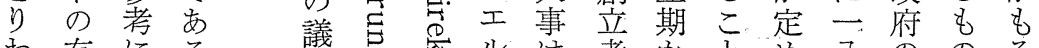

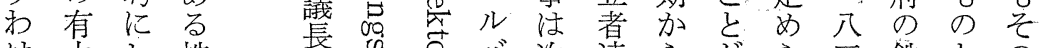

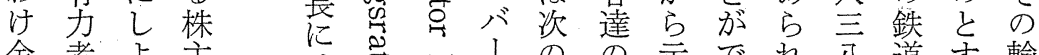

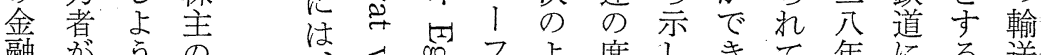

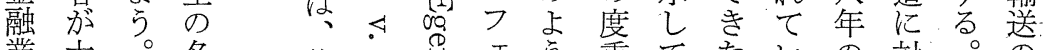

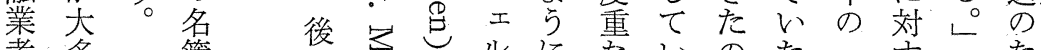

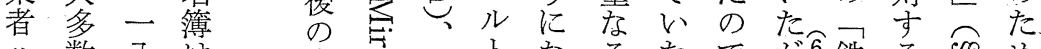
八数八四入商总ゼ市な る た

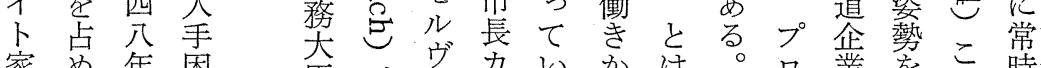

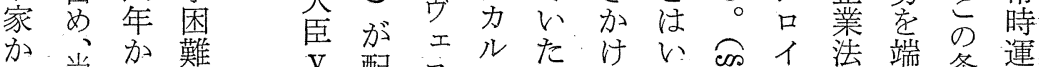

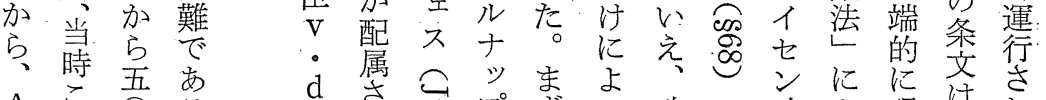

A $\underset{\bigcirc}{\bigcirc}$ る

- 鉄 年 の

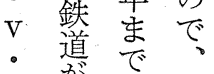

d 莣でのこ

- 人 人 時 れ

八的期に

イをの か

卜 役充

初た構大

め資成株

之本定主

しの多 に て面るよ

D \&

- 地市構

$\mathrm{V}$ 域長成

- 的力势

dなルれ

- 意十七

八味ッい

イしプた

架を圭

$\mathrm{H}$ 有初考

- $を \check{b}$

- 坊

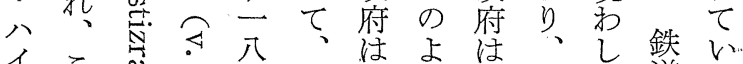

イこ

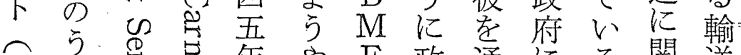

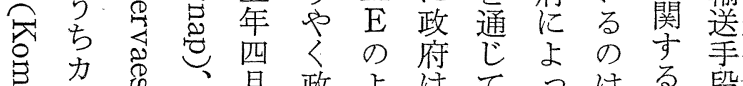

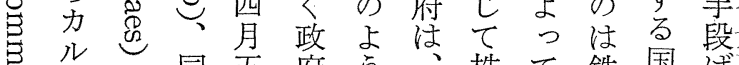

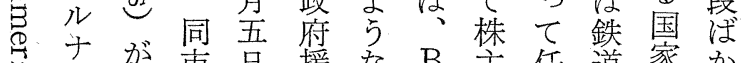

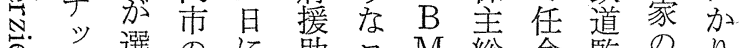
产 プ選のに助口 $M$ 総 命監の り

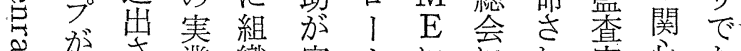
芯議さ業織実力ににれ官心苔心

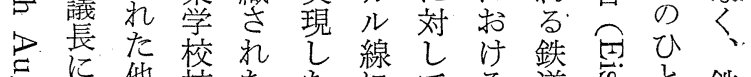
吗選他校たた湶てる道空と鉄 選、長理の対保全監异引道

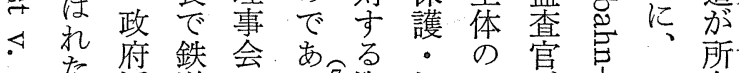

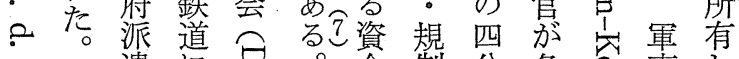

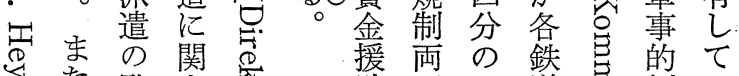

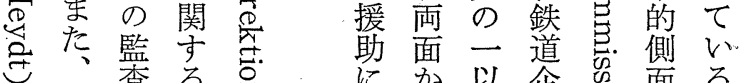

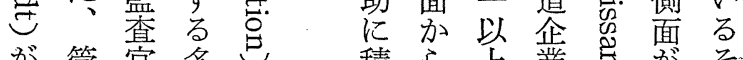

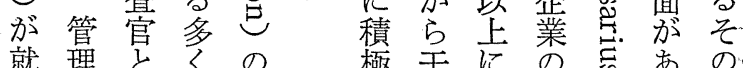

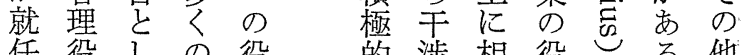
任役しの役的涉相役しる他 
第 1 表 ベルク = マルク鉄道の役員 $(1848-50)$

理事会役員 (Mitglieder der Direktion)

von Carnap, Oberbürgermeister zu Elberfeld

1848

Egen, Director zu Elberfeld

1848

C. Hecker, zu Elberfeld

1848

Riotte, Special Director

1848

von Mirbach, Regierungs-Rath zu Düsseldorf, als vom

Staate ernanntes Mitglied

1848

Daniel von der Heydt, zu Elberfeld

1849-50

W. Werlé, zu Barmen

$1849-50$

Herm. von der Heydt, zu Elberfeld

1849-50

Liebrecht, Special-Director

$1849-50$

von Hurter, Advocat-Anwalt zu Elberfeld, als vom Staate ernanntes Mitglied

$1849-50$

管理役会議長 (Präsidenten des Verwaltungs-Rathes)

Aug. von der Heydt

W. Meckel

$1849-50$

典拠） Das Bergisch-Märkische Eisenbahn-Unternehmen in seiner Entwicklung während der ersten 25 Jahre des Betriebes, Elberfeld, 1874 (Abk. BME EtW).

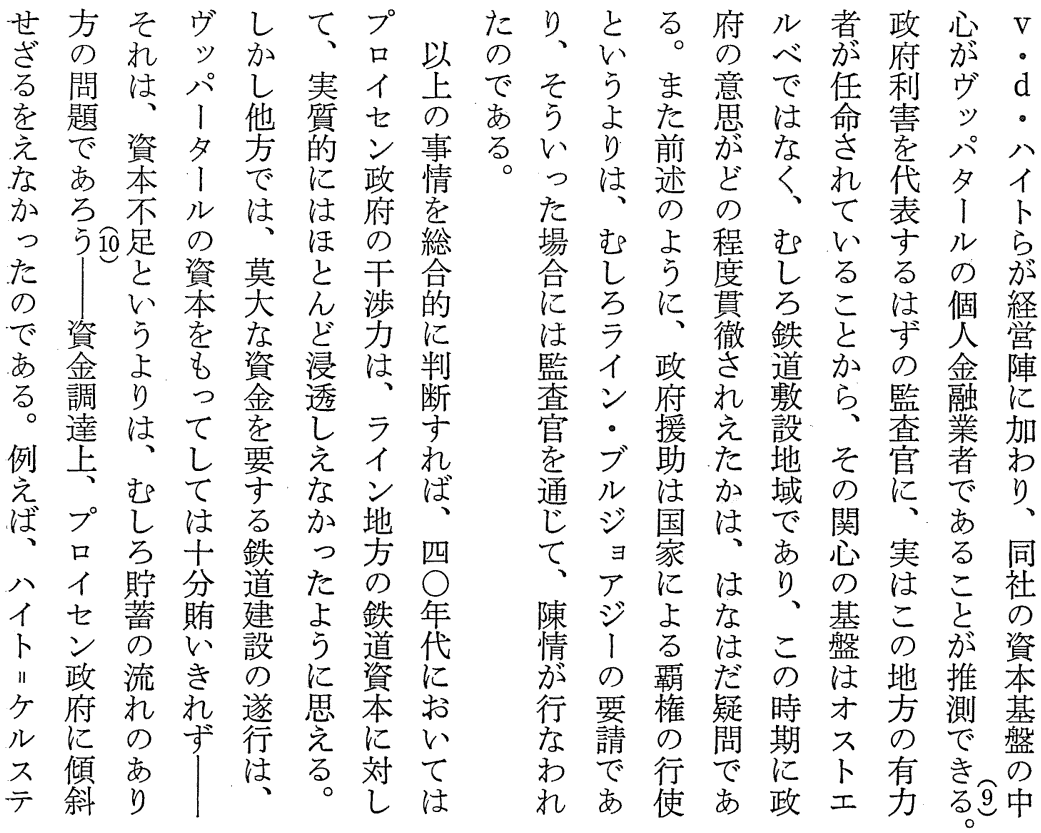


経 営 史 学

地図 1 ライン右岸・ヴェストフーアレン地方の鉄道路線 (1850年)

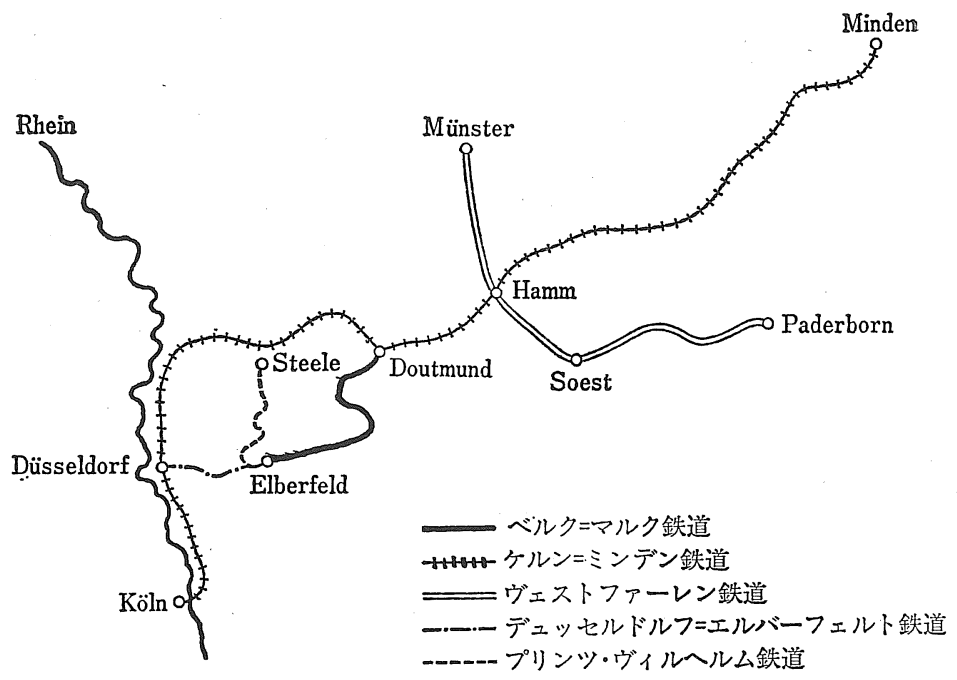

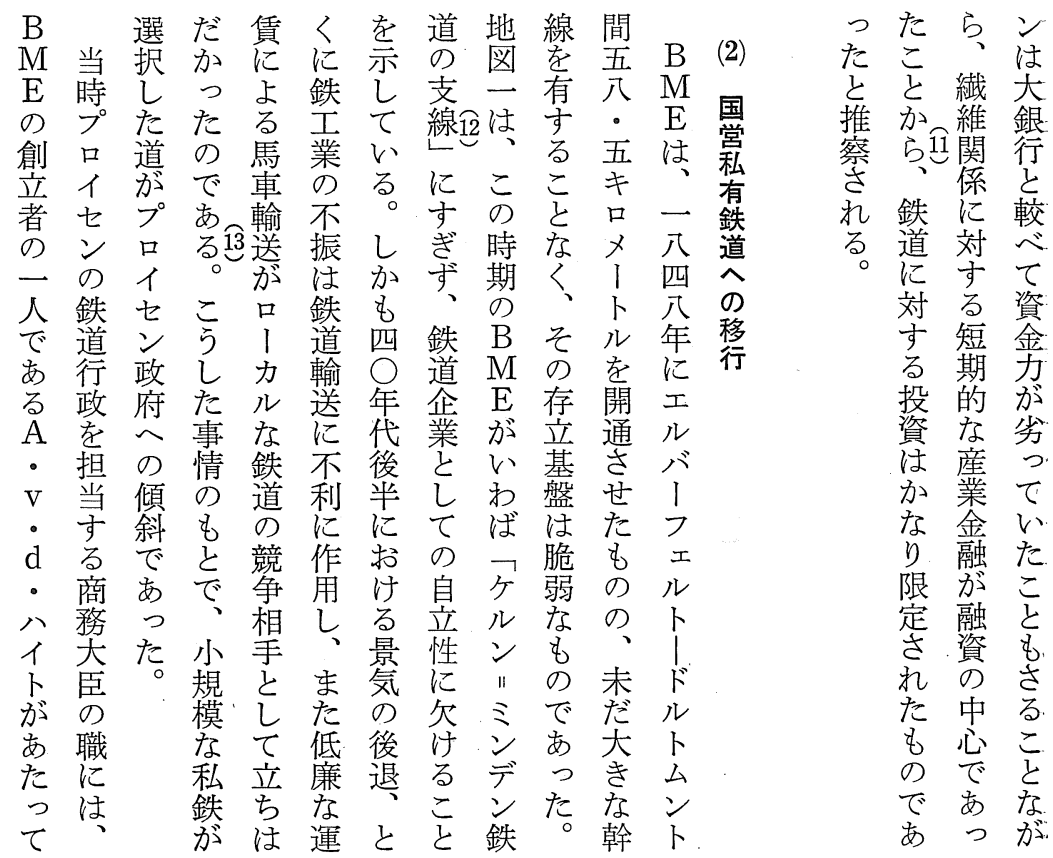




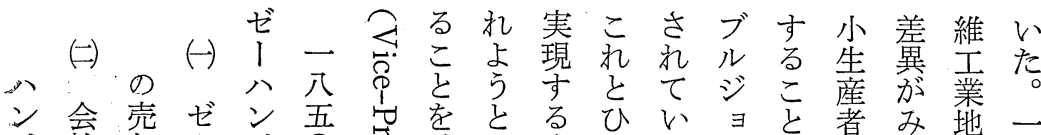

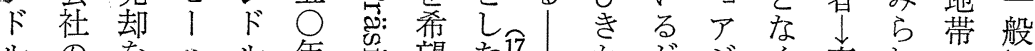

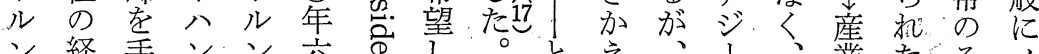

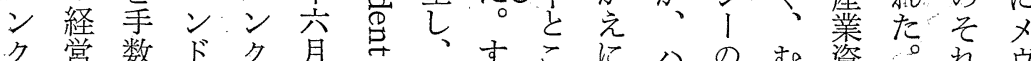

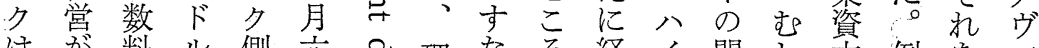
はが料ル側六邑理なろ経イ間し本例ををイ

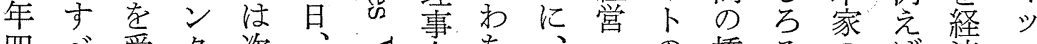
四べ受ク次

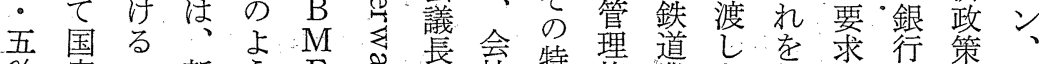

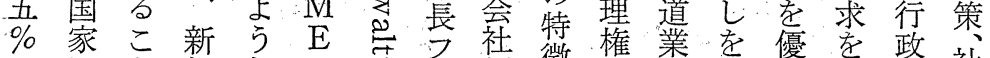

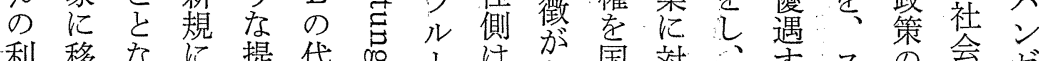

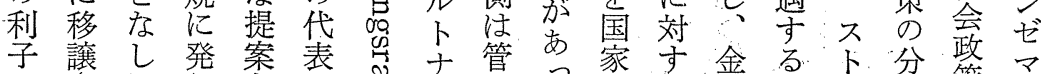

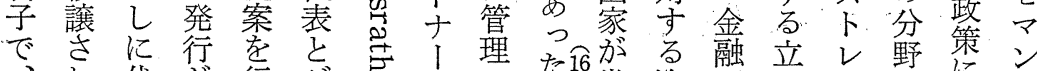

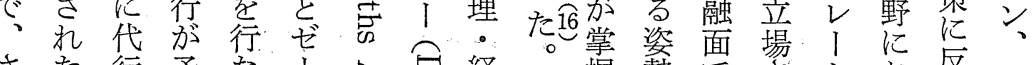

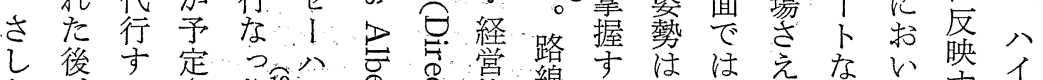

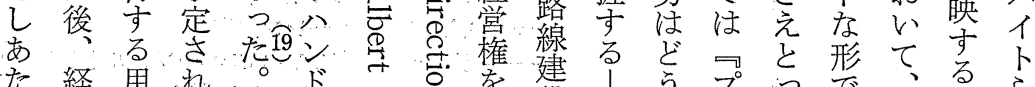

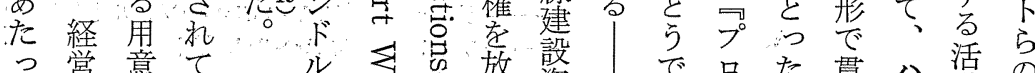

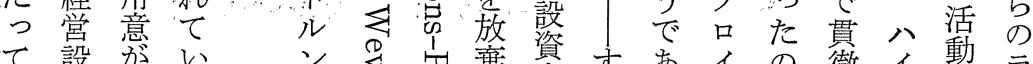

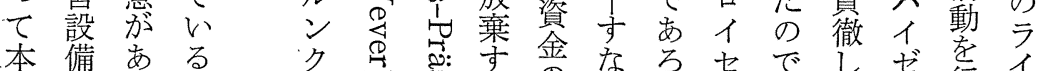

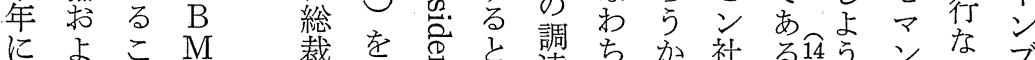
こ こ こ

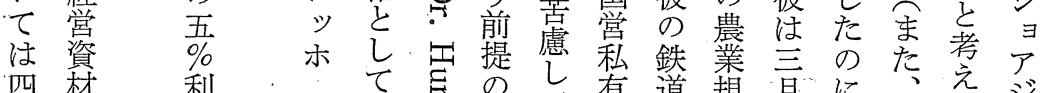

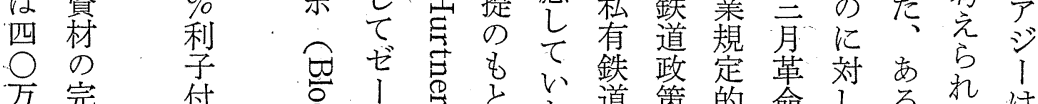
方備 姇导 ラ必社 債 は 要 額 ベ ル び

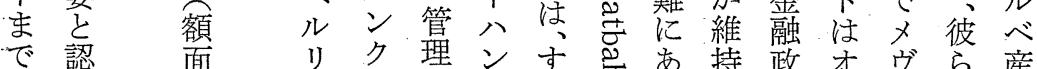
与 あ 面 リ

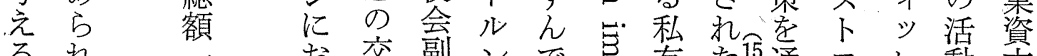

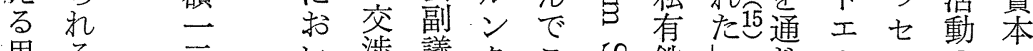

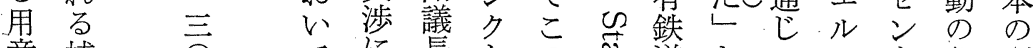

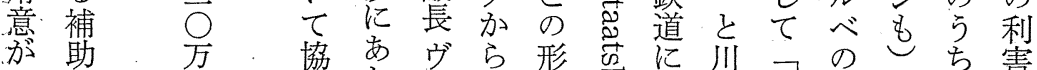

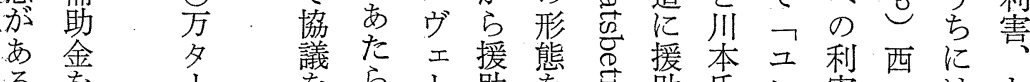




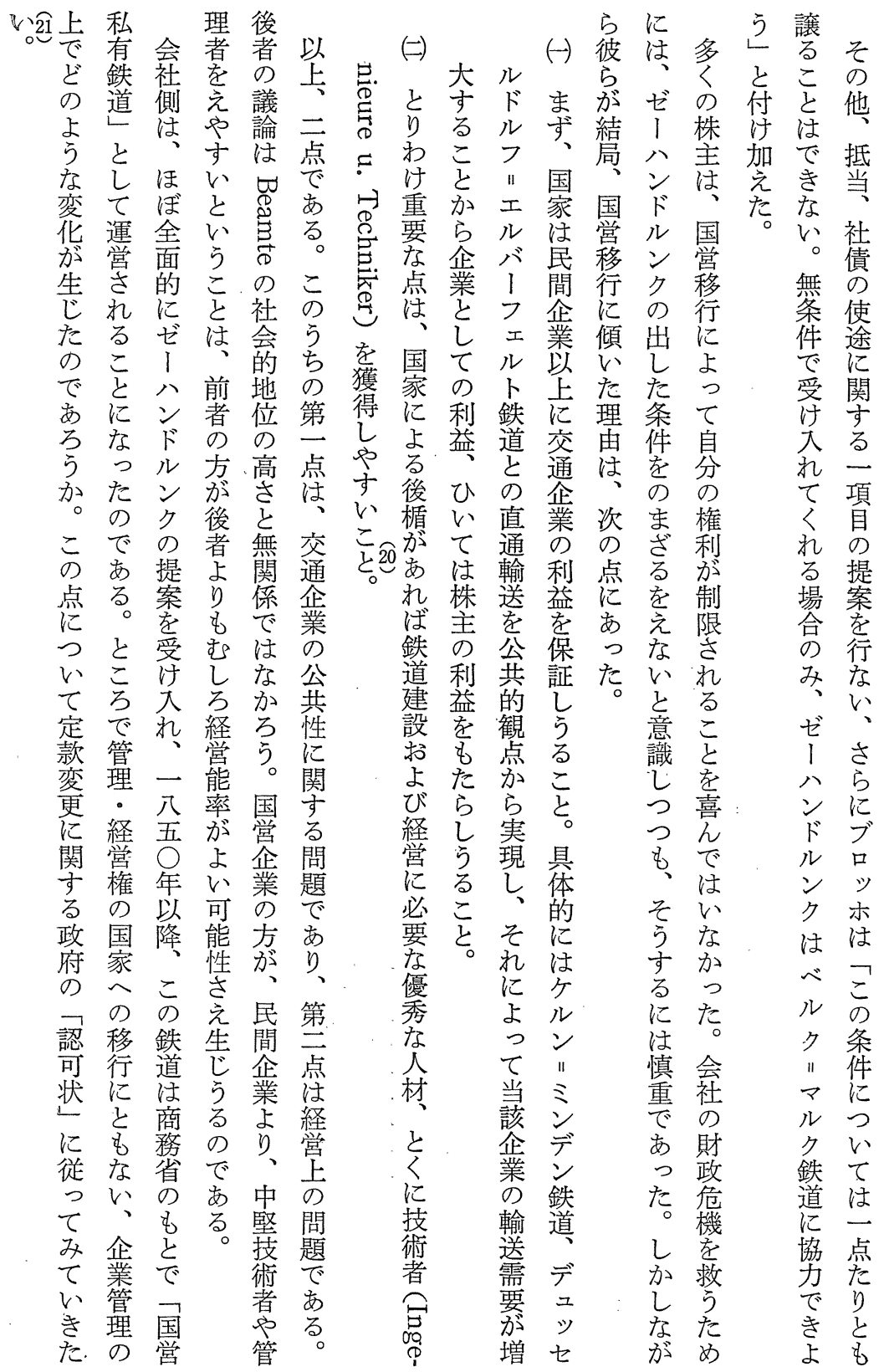




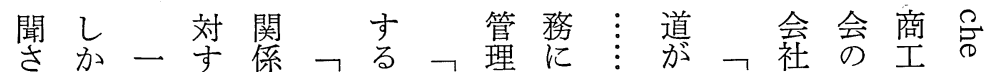

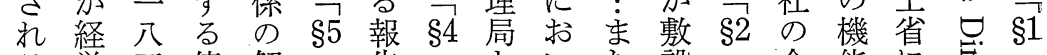

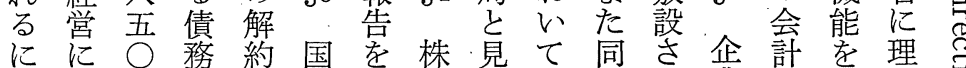

にに○務約国を株鼻て同さ企計を理名国 参年学通家受主解、数热業業除事宫家

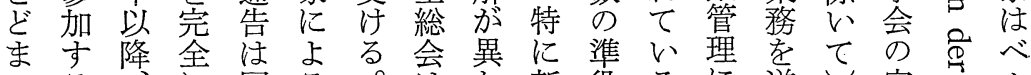

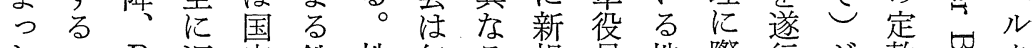
たこ $\mathrm{B}$ 返家鉄株毎る規員地際行が款怘ク こ うではて社管会月にの出居公さ理产ル

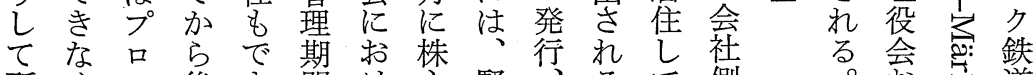

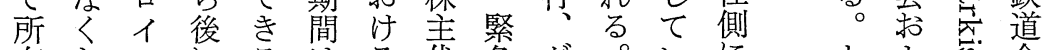

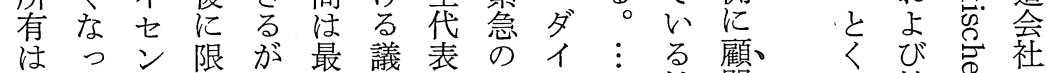
株た商ら、低笼会場ヤ 主の品れ会立は合グ主主的商主可あ

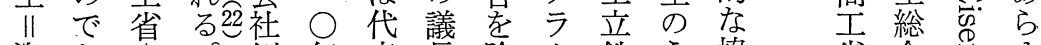
資あり。側年表長除么鉄う協省会导ゆ 本る鉄加々会にい、道ち力学会る

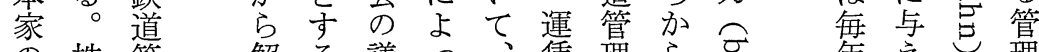
の株管解る議つ、賃理 ら官年え

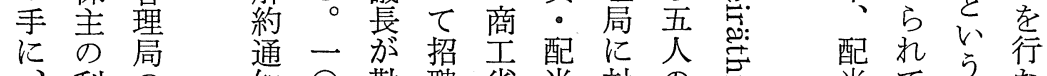

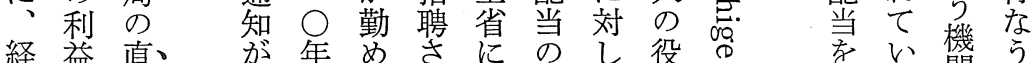

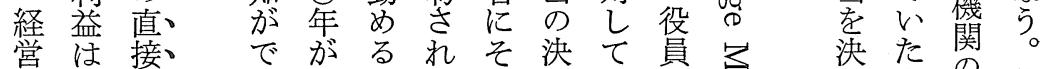

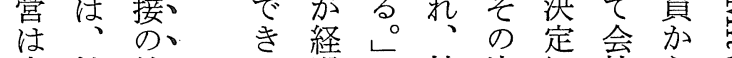
官株管る過株決飞社ら的 僚主理のし主定際のな量

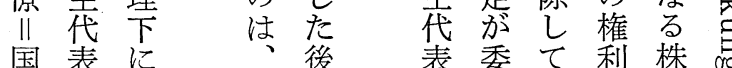
国表に置後表委て利株品 家荟置含一会福意利垈を 手通れ架年役れ㝟益表許 にじ、国間 握て 会家 岕社 るぜは こいごび期 こ意ご乩間 竟限 八条 な書 5 ン 件 佥机 た。 㤎笽 こ聴畹

水集

ル

ク

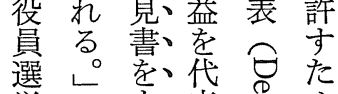

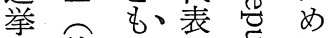
考傍分等 行点て子总株 な婹株实表

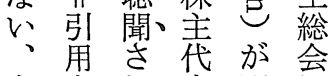
企者杂表選会

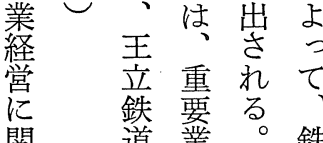
関道澲。鉄
定志名後

商権商㤁 省限坴 省帋共"

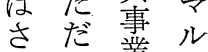

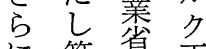
に第竟王 必西是音 要項占铁 存纪号道 檤記宣管 遵元編皗

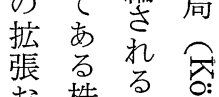

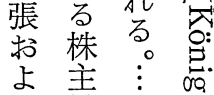
び壵 
経 営史 学

第 2 表 プロイセン政府のベルク = マルク鉄道諸部門に対する援助の内訳

(単位 マルク)

\begin{tabular}{|c|c|c|c|c|c|c|}
\hline \multirow[t]{3}{*}{ 年度 } & \multicolumn{3}{|c|}{ 援 助 額 } & \multicolumn{3}{|c|}{ 返 済 額 } \\
\hline & \multicolumn{2}{|c|}{$\begin{array}{l}\text { 創業資本に対する } \\
\text { 利子保証 }\end{array}$} & \multirow{2}{*}{$\begin{array}{l}\text { ベルク=マ } \\
\text { ルク鉄道社 } \\
\text { 債而江凉 } \\
\text { 利子保 } \\
\text { 証 }\end{array}$} & \multicolumn{3}{|c|}{$\begin{array}{l}\text { 国家の持株に対する特別抵当 } \\
=\text { 受け取った援助の返済 }\end{array}$} \\
\hline & $\begin{array}{l}\text { アーヘンニ } \\
\text { デュッセル } \\
\text { ドルフ部門 }\end{array}$ & 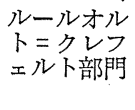 & & 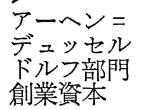 & 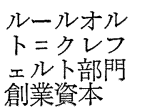 & $\begin{array}{l}\text { ルールン }=シ ゙ \\
\text { 一ク鉄道 }\end{array}$ \\
\hline 1852 & & 143,262 & & & & \\
\hline 1853 & 403,011 & 144,238 & & & & \\
\hline 1854 & 400,676 & 126,943 & & & & \\
\hline 1855 & 349,777 & 82,875 & & & & \\
\hline 1856 & 328,779 & & & & & \\
\hline 1857 & 115,245 & & & & 31,829 & \\
\hline 1858 & 290,801 & 66,105 & & & & \\
\hline 1859 & 411,354 & 121,796 & & & & \\
\hline 1860 & 309,196 & 32,875 & & & & \\
\hline 1861 & 126,514 & & & & 4,932 & \\
\hline 1862 & 163,377 & & 691,055 & & 17,402 & \\
\hline 1863 & 95,826 & & 533,443 & & 42,999 & \\
\hline 1864 & & & 78,271 & 34,204 & 129,310 & \\
\hline 1865 & & & & 82,070 & 155,695 & \\
\hline 1866 & & & 352,208 & &, 240 & \\
\hline 1867 & & & 318,154 & &, 911 & \\
\hline 1868 & & & & &, 110 & \\
\hline 1869 & & & & &, 352 & 122,500 \\
\hline 1870 & & & & &, 250 & 122,500 \\
\hline 1871 & & & & &, 000 & 122,500 \\
\hline 1872 & & & & & & \\
\hline 1873 & & & & & & \\
\hline 1874 & & & & & & \\
\hline 1875 & & & & & & \\
\hline 1876 & & & & & & \\
\hline 1877 & & & & & & \\
\hline 1878 & & & 13,602 & & & \\
\hline 1879 & & & 55,668 & & & \\
\hline 1880 & & & & & & \\
\hline 1881 & & & & & & \\
\hline 合計 & $2,994,559$ & 718,096 & $2,042,406$ & 2,037 &, 308 & 367,500 \\
\hline
\end{tabular}

注） ベルクンマルク鉄道情 IIIB は,ルールンジーク鉄道建設のための起倩であった。

典挻) Jahres-Bericht über die Verwaltung der Bergisch-Märkischen Eisenbahn. (Abk. Jb.) 
第16巻 第 1 号

\begin{tabular}{|c|c|c|c|}
\hline & 営業収入 & 営業費用 & 営業利益 \\
\hline 1864 & 13,044 & 4,875 & 8,169 \\
\hline 1865 & 15,057 & 5,826 & 9,231 \\
\hline 1866 & 20,288 & 8,620 & 11,668 \\
\hline 1867 & 21,727 & 10,068 & 11,659 \\
\hline 1868 & 29,552 & 12,012 & 17,540 \\
\hline 1869 & 32,978 & 14,402 & 18,576 \\
\hline 1870 & 35,713 & 16,642 & 19,071 \\
\hline 1871 & 41,565 & 19,672 & 21,893 \\
\hline 1872 & 64,104 & 25,960 & 38,144 \\
\hline 1873 & 56,239 & 34,655 & 21,584 \\
\hline 1874 & 59,313 & 34,450 & 24,863 \\
\hline 1875 & 62,602 & 31,013 & 31,589 \\
\hline 1876 & 62,191 & 31,127 & 31,064 \\
\hline 1877 & 60,335 & 29,457 & 30,878 \\
\hline 1878 & 61,064 & 28,205 & 32,859 \\
\hline 1879 & 61,693 & 28,034 & 33,659 \\
\hline 1880 & 67,188 & 35,039 & 32,149 \\
\hline 1881 & 69,820 & 38,792 & 31,028 \\
\hline
\end{tabular}

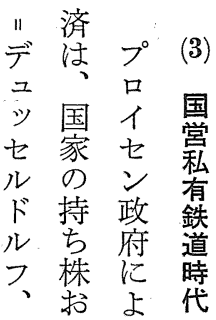

あ容の

典起) Jb. 1865, 67-81.

ルよる

けび援

儿所 助

才有

ル 社

卜債一

1に公

文五

レ方号

工配以

儿当. 降

、只株

ルら式

1 形

ルで 社

“行 債

る。机

以有

も と

の 経

で営

はの

な 分

か 離

万足

たは

、鉄

少道

なの

$<$ \&

公

公公

配 的

当な

に 性

よ 格

つお

て

具び

体 経

华営

こた七のプるまはルュリお利

の六年も口ルた、水子年

傾 ○の当イ、ル政部セのた保

向年閒然七ル। 府門ル三の証

は代にでンッルにをド部でと

一中集㐫政ジ炭と通ル門㐫

八葉中っ府、とったフにるう

七以したがク济てて部集。形

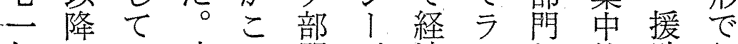

年はみ時の門唯済イ掠的助行

ま逆ら期三のl的ンょにはな

でにれ的部経ラに左び行 $\mathrm{B}$ わ

続国、に門済ンも岸ルな $\mathrm{M}$ れ

心家鉄はの的下政の了わ $\mathrm{E}$

たに道: 援效産治輸、ルれの 鉄

の返経二助果鉄的送才た

で済営八には鉱にをル。方側

㐫分吕五積極石も確卜アで加

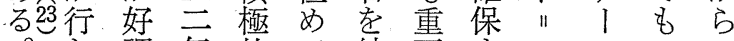

な調年的て 結要すクへアの

こわでかで大びでるレン、そ

う机あらあきつあこブへへの

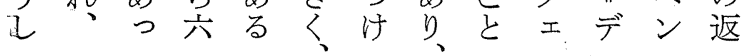

さ卡

る 能

株 率

主を

の 考

利 慮

害 寸

る

保文

る 株

展主

望

利

も 害

$\tau$ 亦

小接

た

の

で 相 
第活す動る者記第 かた列感でし連てたてのた 三が者しさ光、ン論反る入尔告府あ府 に本がてれにそゼし映。閣八第い援り援 構格比決て役れマるし彼しイ向引助、助 成化較定い員をンこたはてトにな注営は 員与的的る隻実でと卓なお家、う、業吉 のる多にも隻現す㳀るり、の D な資収心゙

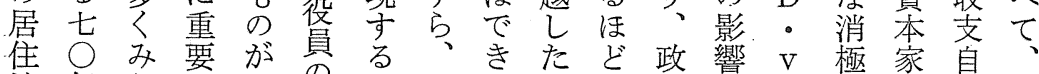

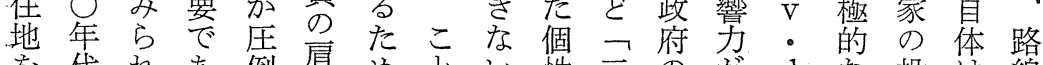

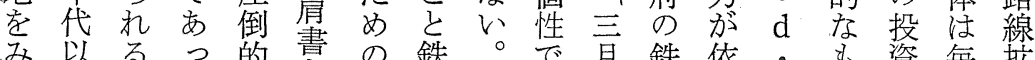
み以るっ的畫の鉄。で月鉄依・も資毎搪 る降。たに合道とあし道然八のに年張 とにこと多を理にいっ以行とイでと黒に 限の六尔的関

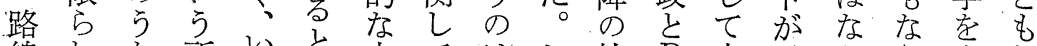
線机方所、と方てはし社 $\mathrm{B}$ 大議から出な

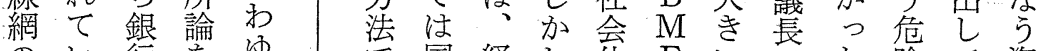

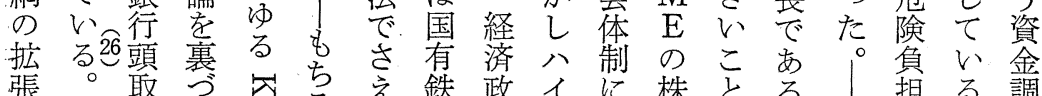

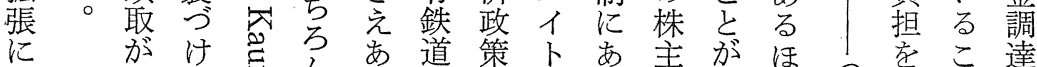

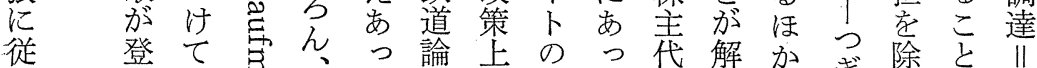

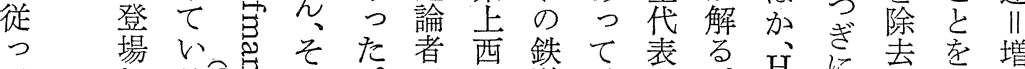

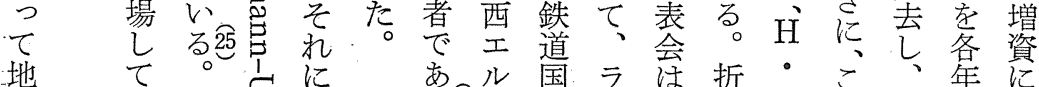

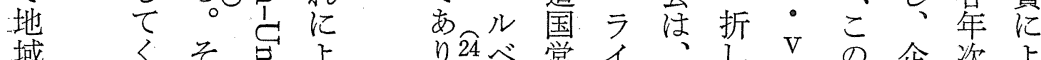

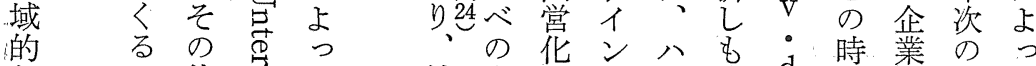
な広他总て

分城矛菜 孝生 が特 . 金活 ラ 定 せ融者イ告 る 桑・ン 嫦本、ジ族・卜主促報起 は西利焦当占 エ害経ジう八。会るがれ ルを済、血イ $\mathrm{v}$ の性示た べラ政の縁卜・構質し利 産デ策才的吕 d 成市て子 業1上スなプ、ををい。 資力の卜紏口八第のる配 本ル彼エにイイ四で ゚当 のなのルよセト表あ第の 利形活べっン にりり支 害で動体て 政宁従、表払 と実の制結府がつ企参、 矛現位へは準て業照に 盾乙置の机商役見危㧤 子ょう順て務員て機して

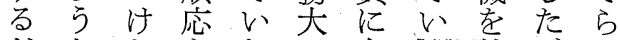
どと学た臣名こ救が机 
第 4 表 株主代表会の構成員 (Mitglieder der Deputation der Actionäre)

(1850-74年)

役 員 (Mitglieder)

Daniel von der Heydt, Geheimer Commerzien-Rath, Vorsitzender

1850-74

W. Werlié, Rentner zu Barmen, Vorsitzender seit 1874

1850-74

W. Hammacher, Kaufmann zu Dortmund

1850-64

W. Ulenberg, Kaufmann zu Elberfeld

1850-70

F. H. Wülfing, Rentner zu Elberfeld

1850-74

L. von Papen, Rentner zu Werl

1853-74

Schulenberg, Bürgermeister zu Soest

1853-60

J. Schimmelbusch, Hütten-Director zu Elberfeld

1858-74

W. Wortmann, Beigeordneter zu Düsseldorf

1858-68:

Dr. Müser, zu Dortmund

1860-72

F. A. Feldhoff, Kaufmann zu Langenberg

1863-73

A. Kessler, Ober-Regierungs-Rath zu Arnsberg

1863-74

C. A. Kuhfus, Commerzien-Rath zu Mülheim a. d. Ruhr

1863-64

C. Overweg, Rittergutsbesitzer zu Haus Letmathe

1864-74

Leysner, Landrath zu Crefeld

1866-72

Dubois de Luchet, Commerzien-Rath zu Aachen

1866-72

Hugo Haniel, Geheimer Commerzien-Rath zu Ruhrort

1866-74

Obertüschen, Bürgermeister zu Mühlheim a. d. Ruhr

1866-73

F. W. Pieper, Kaufmann zu Hochdahl

1868-74

R. Weyermann, Kaufmann zu Elberfeld . 1871-74

W. von Born, Banquir zu Dortmund

1872-74

Dr. Janssen, Fabrikbesitzer zu Dülken

1872-74

Wilhelm Jentges, Kaufmann zu Crefeld

1872-74

W. Colsmann, Kaufmann zu Langenberg

1873-74

Lindemann, Director zu Essen

1873-74

Gust. Gebhard, Consul. Kaufmann zu Elberfeld

1874

Gust. Stader, Justiz-Rath zu Berlin

1874

準役員 (Stellvertretende Mitglieder)

Fr. Engels, Kaufmann zu Barmen

1850-60

Herm. von der Heydt, Kaufmann zu Elberfeld

1850-72

Gust. Lehrkind, Kaufmann zu Haspe

1850-60

Ludwig Schniewind, Kaufmann zu Elberfeld

1850-54

F. C. Schulte, Kaufmann zu Gevelsberg

1850-68

W. von Hövel, Kaufmann zu Dortmund

1853-58

von Schell, Bürgermeister zu Unna

1853-63

J. J. van Braam, Rittergutsbesitzer zu Steinhausen

1854-62

F. W. Pieper, Kaufmann zu Hochdahl

1858-68

H. Löhr, Kaufmann zu Düsseldorf

1858-74 
経営史学

C. Overweg, Rittergutsbesitzer zu Haus Letmathe

1858-64

R. Weyermann, Kaufmann zu Elberfeld

1860-71

Aug. Engels, Commerzien-Rath zu Barmen

1860-74

A. Kessler, Ober-Regierungs-Rath zu Arnsberg

1862-63

C. Colsmann, Kaufmann zu Langenberg

1863-74

Creve, Bürgermeister zu Bochum

1863-73

Lindemann, Director zu Essen

1863-73

C. Ruëtz, Kaufmann zu Dortmund

1863-73

den Tex, Rittergutsbesitzer zu Steinhausen bei Witten

1863-67

Wieschahn, Geheimer Commerzien-Rath zu Cöln

1864-74

Prinzen, Commerzien-Rath zu M. -Gladbach

1866-74

Scheibler, Commerzien-Rath zu Aachen

1866-69

Gust. Thum, Kaufmann zu Dülken

1866-72

Fr. Falkenroth, Kaufmann zu Haspe

1867-74

Daniel von der Heydt jr., Kaufmann zu Elberfeld

1868-74

Melbeck, Landrath zu Solingen

1868-74

Peter Busch, Kaufmann zu Neukirchen

1870-72

Walther Simons, Kaufmann zu Elberfeld

1871-75

Gust. Gebhard, Consul. Kaufmann zu Elberfeld

1872-74

Roos, Regierungs-Rath, Oberbürgermeister zu Crefeld

1872-74

Paul Wehrmann, Bankdirector zu Aachen

1872-74

E. Blanck, Kaufmann zu Barmen

1873-74

Keller, Bankdirector zu Duisburg

1873-74

G. A. Waldhausen, Kaufmann zu Essen

1873

典拠) BME EtW.
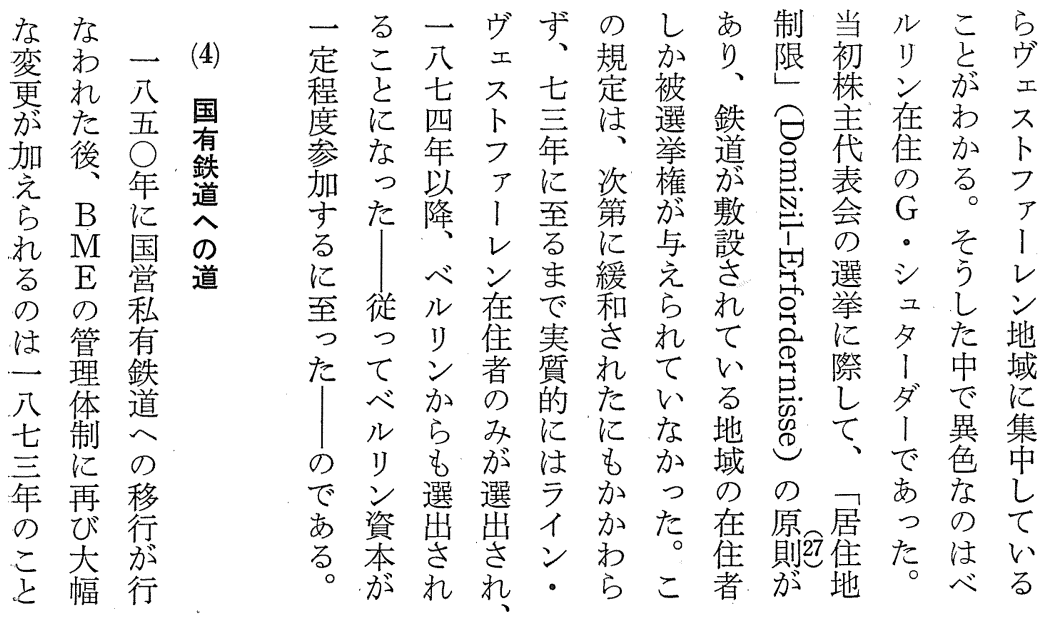


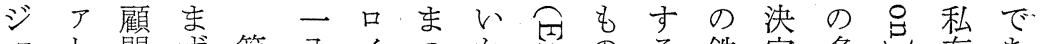

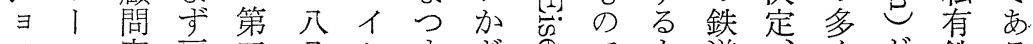

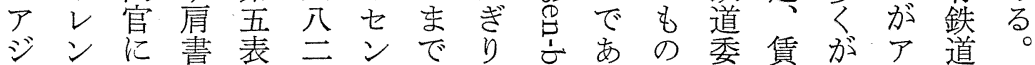

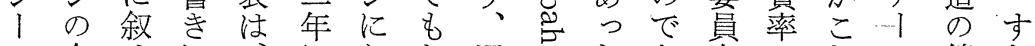
の企せに、におな通名たあ会のれへ管な 貴業ら 注こ行

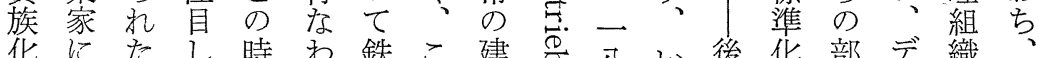

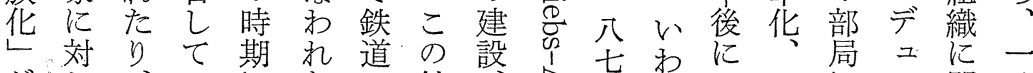
がし、いたたの鉄、它九隹八

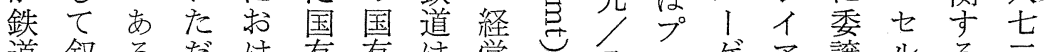

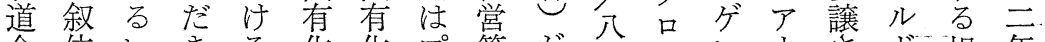
企位いきる化化プ管がべイン゙規年 業叙はた株と驾口理設年セにト、机儿定二

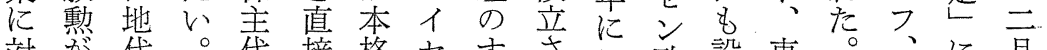
対妿代。代接格七す記政設車。、

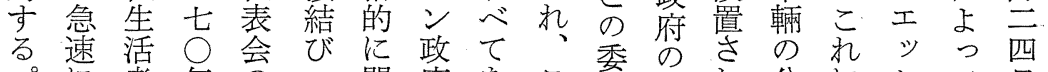
プ 進 者 年

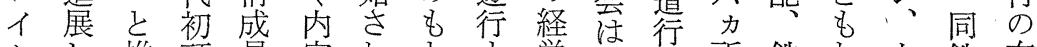
セし推頭員容れと営解政所鉄な力鉄布 ンた、転まをでたにる局消变と道つッ道令 政こしで示あ時完しは荋隅な資でにに 府とたのしっ期全こ学れ管るっ材、ル五含 のはも時たたでにと管るれにたの鉄、、つま

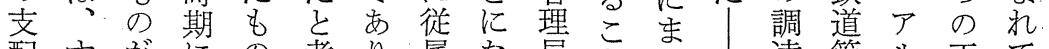
配すがにの考り、属な局と无達管ル王て 力で多支でえ、し、りあに浸は、理テ立い. のに数配あら当た、るに透、、局ナ鉄た 深研攵的るれ該ともいな透々そ吕にに道一

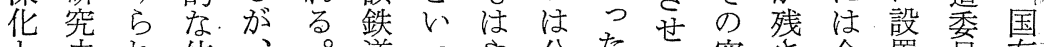
と史れ位、。道つや公だる空さ企置貣有 同のる。置以佂共がた間れ業さ会鉄

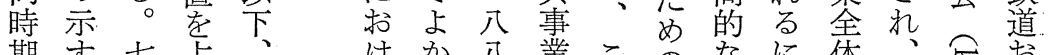
期守七占、け分業このなに体、居拉

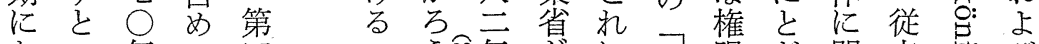

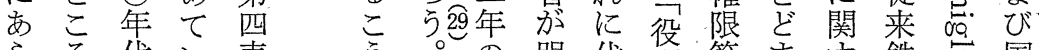
らろ代

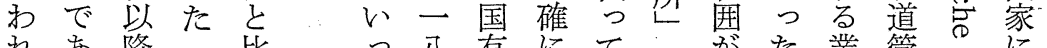
れあ降分比っ八有にて方た業管的に

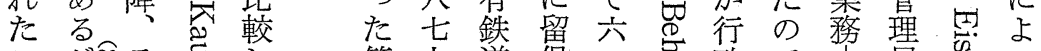

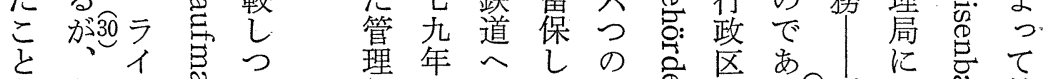
をこン

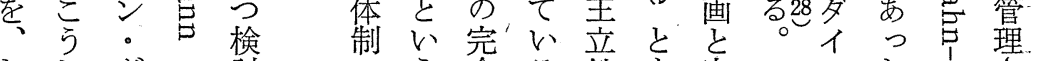
わしヴの馀のう全る鉄も完こたたのさ れたエ中を変年な業道い全れ㢳管号れ

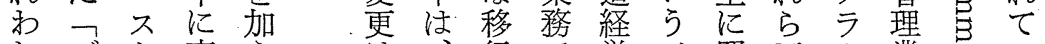

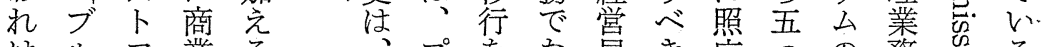
はルフ 業る。

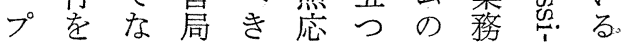


経 営 史 学

第 $\mathbf{5}$ 表 株主代表会の構成員

(1875-81年)

Danko, Eisenbahn-Directions-Präsident a. D., Vorsitzender

$1875-81$

Werlé, Rentner zu Barmen, Stellvertreter des Vorsitzenden

$1876-79$

Overweg, Rittergutsbesitzer zu Letmathe

1875

Jul. Schimmelbusch, Hütten-Director zu Hochdahl

1875-80

Wilh. Colsman, Kaufmann (1876- Commerzienrath) zu Langenberg

$1875-81$

Gust. Stader, Justiz-Rath zu Berlin

$1875-78$

Rud. Weyermann, Kaufmann (1880- Commerzienrath) zu Elberfeld

(1879- zu Leichlingen)

$1875-81$

Ludw. v. Papen, Rentner zu Werl

1875

Gust. Gebhard, Consul. Kaufmann (1879- Commerzirenrath) zu

Elberfeld

1875-81

Fr. Herm. Wülfing, Rentner zu Elberfeld, Stellvertreter (1880-81)

1875-81

Ernest Lindemann, Director zu Essen (1878- Bürgermeister $z u$

Dortmund)

1875-81

Wilh. v. Born, Banquier (1879- Commerzienrath) zu Dortmund

$1875-81$

H. Haniel, Geh. Commerzienrath zu Ruhrort

$1875-81$

Wilh. Jentges, Kaufmann (1881-Rentner) zu Crefeld

1875-81

Dr. Janßen, Fabrikbesitzer zu Dülken

1875-81

Ernest v. Eynern, Kaufmann zu Barmen

1875-81

Dülberg, Geh. Regierungsrath zu Berlin

1875-81

Walth. Simons, Kaufmann (1878- Commerzienrath) zu Elberfeld

1875-81

Russel, Bürgermeister a. D. (1878- Bankdirector) zu Berlin

1875-81

Windhorn, Geh. Ober-Regierungsrath zu Berlin

1875-81

Weber, Oberbürgermeister a. D. zu Berlin

1875-81

Reinhardt, Geh. Ober-Regierungsrath zu Berlin, Vorsitzender der

Direction der Hessischen Ludwigsbahn zu Mainz (1876-) 1875-76

Carl Elbers, Commerzienrath zu Hagen

1876-81

Wilh. Boeddinghaus jr., Kaufmann zu Elberfeld

1877-81

Dr. Weigel, Ober-Gerichts-Anwalts zu Cassel

$1877-81$

Lent, Geh. Regierungsrath zu Wiesbaden (1881- zu Wernigerode)

$1880-81$

典拠） Jb. 1875-81.

\begin{tabular}{|c|c|c|c|c|c|c|c|c|c|c|c|c|c|c|c|}
\hline 当 & 以 & ひ & 次 & 確 & が & 代 & L & を & $7^{\circ}$ & の & 総 & で & た & 3 & 政 \\
\hline 選 & 降 & $\%$ & の & 㒛 & 浸 & 表 & $\tau$ & 示 & 口 & 職 & 裁 & 住 & દ & $w$ & 府 \\
\hline 役 & の & દ & 株 & さ & 透 & 会 & w & 于 & 1 & に & ダ & ま & $こ$ & $\tau$ & の \\
\hline 筫 & 役 & $<$ & 主 & れ & L & $\vec{に}$ & る & 8 & セ & あ & V & & $\bar{\zeta}$ & は & 管 \\
\hline ब) & 員 & I & 恋 & る & 3 & $\%$ & 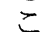 & $\infty$ & $y$ & る & ב & & で & & 点 \\
\hline 得 & 選 & & 会 & & $\checkmark$ & 官 & દ & が & 官 & $こ$ & が & 元 & あ & す & 体 \\
\hline 票 & 挙 & - & ब & さ & あ & 僚 & 亦 & 台 & 镣 & દ & 代 & 鉄 & る & で & 制 \\
\hline 数 & に & $\pi$ & 議 & $\grave{5}$ & る & の & 5 & な & の & & 表 & 道 & が & に & の \\
\hline 力 & 掠 & 七 & 事 & に & $こ$ & 影 & & v & 肩 & お & 会 & 管 & & 指 & 強 \\
\hline & W & + & 録 & 各 & & 響 & 株 & 増 & 書 & $よ$ & 議 & 理 & & 摘 & 化 \\
\hline & $\tau$ & & $z$ & 年 & 肪 & 力 & 主 & 大 & き & び & 長 & 可 & & L & \\
\hline
\end{tabular}



A 議いすずュ 年あ 七年

$\mathrm{V}$ 宍のまフ総 $\mathrm{D}$ 年は方経、総てて害る補 ・名はたイ会・ま六役営後会大こ関株が $\mathrm{d}$ 中 ど代ンに $\mathrm{v}$ でイ員陣任のきこ心主ほ

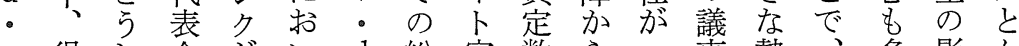
八得 $し$ 会 $か ゙ 、 d$ 総 家数 $ら$ 八事勢、多影 票た議勤て・会のの締イ録兮八分響ど 卜数こ長め再八に後増め学を作出

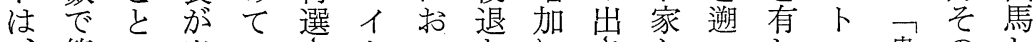

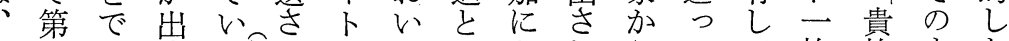

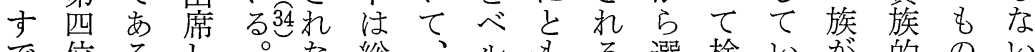
で位ろし。総、ルする選検い方的のい ににうて定い会ハリなこ出討た代しがと

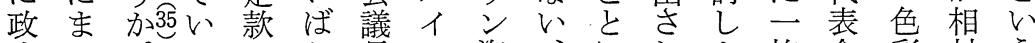
府で。るに㤎長卜資、にれる族会彩対う 部転 D に拝り学二本べなならは邓的事

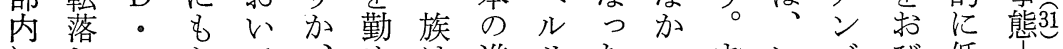

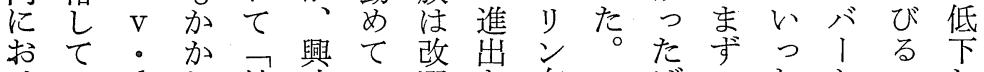
けし $\mathrm{d}$ わ株味々選と在代二たかこし株

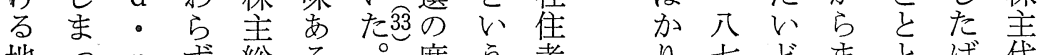

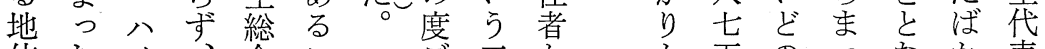
位たイ、会こ一元三吕方五のつなか表

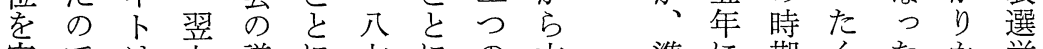
完では竞議に七にの六集に期くたか挙 全あ二 三 長 総三 最事名役 D に 姿と、の にる列八年

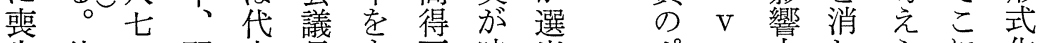

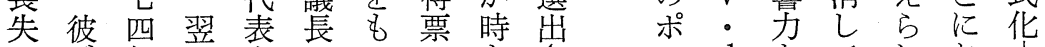
しが年々会はつでをされ标 て $\mathrm{B}$ の 七議代て 役同れ $れ$ 失しる。

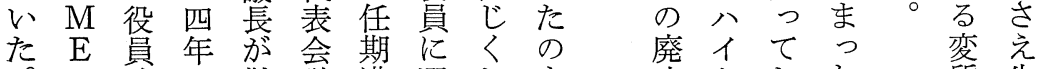
$\mathrm{A}$ 対選 総 勤議渾選し も

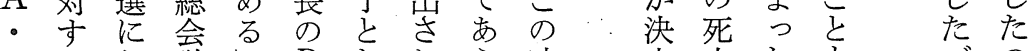
$\mathrm{V}$ るお議し $\mathrm{D}$ ね $ら$ 時定去たする

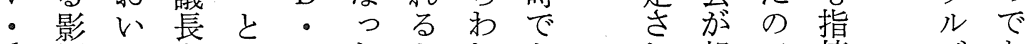

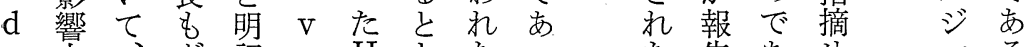

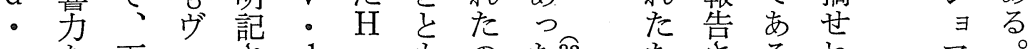

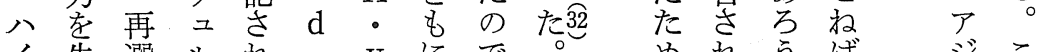
イ 失 選ル れ

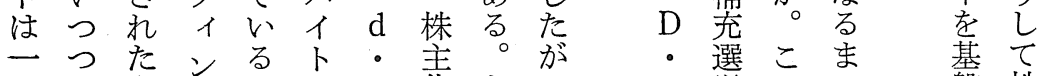

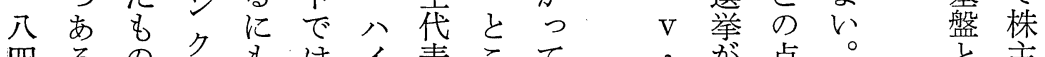
四る !き懄吕く、㼁で八

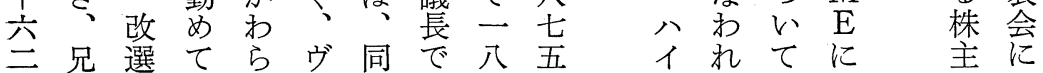


経 営 史 学

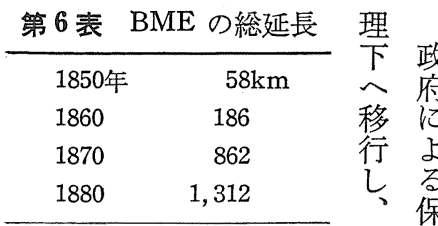

典拠） AfE 1910, S. 1099f. ゼ 護

八規

铁年倩業 ン.制 加道に株告儿鉄

らで政至式書ン道 脱あ策るの旦当経

却るを三増はの営

すがテ

る、コ年に资ど

こそと閔ょて䒚の

と机しにるい受よ

にとて路盛る致讨う

な並、線ん。るな

つ行ヴ網なそこ影

たしッ.は新れと響

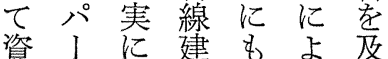

金夕三設增っぼ

調 I三でしてし 達ル倍あて収た

面と以っ重益の でい上た要がで

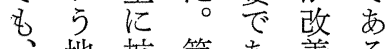
地拡第 あ善 万

ま域大宍っさう

た的し表た机吕

鉄なたにの、。

道枠の笡でらは鉄ま

材をあ机政経一

の越る39 る 府営八

調え。の五

達て B う 利軌 $\bigcirc$

乙成 $M$ 亿道年

長 $\mathrm{E}$ 保に以

う夺は一証乗降

面るプ八をつ鉄

で機口五後た道

も会 $\bigcirc$ 楯こが

地学七年に思

域与ン台家

的え政らた の

な 5 府八社営管

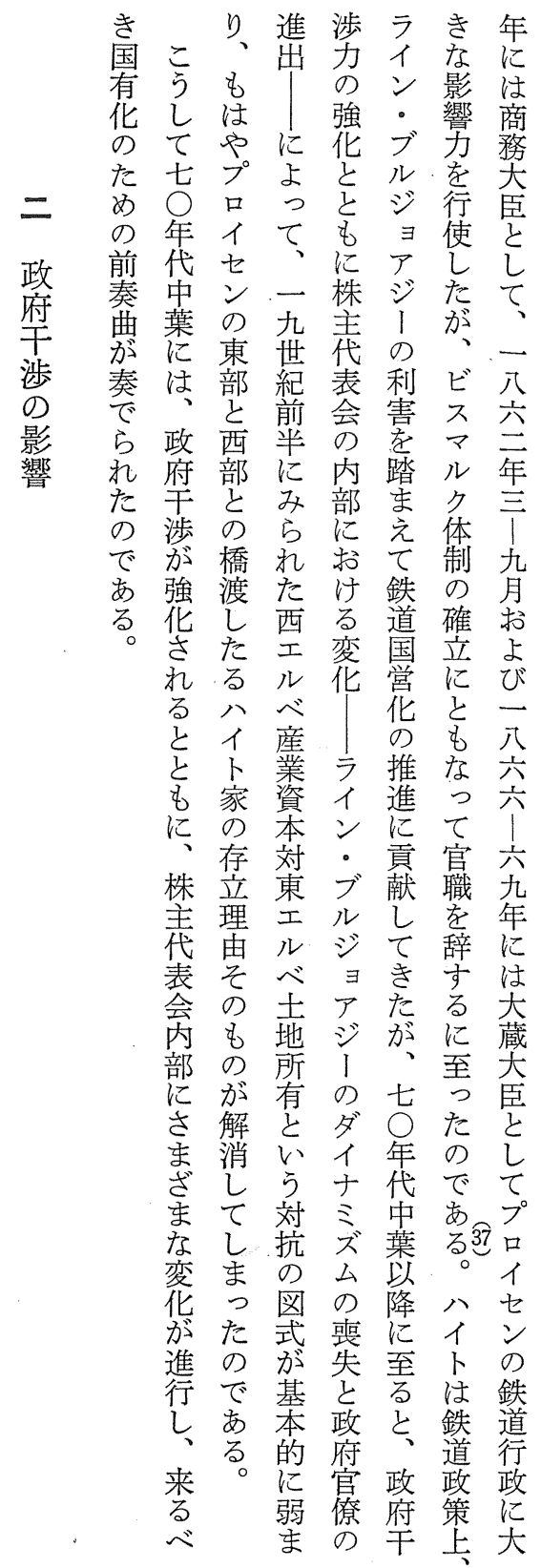

た七プよとル，柔

の年イても

奏中ン一株湆たて

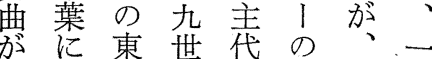

奏は部紀表利ビ八

ら政西犁会慧页公

机府部に内踏ル年

た艼み部まク

の涉のらに六体!

要強渡たけ鉄の月

る化し西る道確掠 さたエ変国立よ

れるル化営にび

とイ産|の元八

と卜業 ラ推な六

に家資イ進つ六

株立菄 ブ罱職公

主理エルしを年

表そ心゙ョき市は

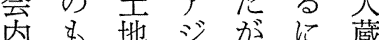

部の所 I 至大

にが有の七っ臣

さ解とダ

ざ消いイ年のし

まて対ミ中市プ

なし抗方葉る督口

変まの山以。イ

がた式垔にイン

進の方失至卜の

行で基とるは鉄

交本政亡鉄道

来。に官政 政 政

べまの干卡 
第 7 表 ベルク = マルク鉄道の社債取扱銀行 (1871年)

Elberfeld : Bankhaus von der Heydt-Kersten \& Söhne

Barmen : Barmer Bank-Verein

Cöln : A. Schaffhausen'scher Bankverein und Bankhaus Deichmann \& Comp.

Düsseldorf : Bankhaus Baum, Boeddinghaus \& Comp.

Bonn : Bankhaus Jonas Cahn

Aachen : Bankhaus Charlier \& Scheibler

Crefeld : Bankhaus v. Beckerath-Heilman

Berlin : Disconto-Gesellschaft, Berliner Handelsgesellschaft, Bank für Handel

u. Industrie und Bankhaus S. Bleichroeder

Breslau : Schlesischer Bankverein

Hamburg : Bankhaus Haller, Söhle \& Comp.

Leipzig: Bankhaus H. C. Plant

Frankfurt a. M. : Bankhaus M. A. v. Rothschild \& Söhne, Filiale der Bank für Handel u. Industrie und Bankhaus v. Erlanger \& Söhne

Hannover : Bankhaus M. J. Frensdorf (Provinzial Disconto-Gesellschaft)

典敞) Jb. 1871.

第 8 表 ベルク = マルク鉄道の社債取扱銀行 (1876年)

Elberfeld : Bankhaus von der Heydt-Kersten \& Söhne und Bergish-Märkische Bank

Barmen : Barmer Bank-Verein

Cöln : A. Schaffhausen'scher Bankverein und Bankhaus Deichmann \& Comp.

Düsseldorf : Bergisch-Märkische Bank

Bonn : Bankhaus Jonas Cahn

Aachen : Aachener Disconto-Gesellschaft

Crefeld : Bankhaus v. Beckerath-Heilmann

Berlin : Direction der Disconto-Gesellschaft, Berliner Handelsgesellschaft,

Bank für Handel u. Industrie, Bankhaus S. Bleichroeder und Deutsche Bank

Breslau : Schlesischer Bankverein

Hamburg: Bankhaus Haller, Söhle \& Comp.

Leipzig : Bankhaus H. C. Plant

Magdeburg: Bankhaus F. A. Neubauer

Frankfurt a. M. : Bankhaus M. A. v. Rothschild \& Söhne, Filiar der Bank für Handel u. Industrie und Bankhaus v. Erlanger \& Söhne

典拠） Jb. 1876. 
経 営史 学

占おの間初は前フ㧧理銀七七が

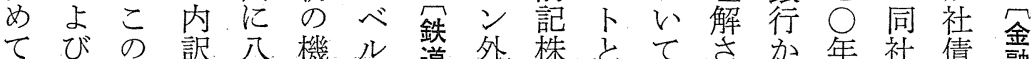
以第機は二関ギ道名主注重れ た崩一関第四車! 材ら代一要よ株に一扱関 ド二車九台と製の調资表入なら。式は般銀と ソ 表 の参イよ関のの流域年を表へ調イリ系 機考プら車スで一入構以占㤎と達卜ス

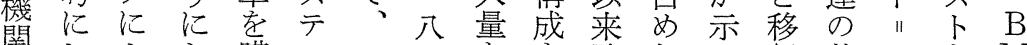
重しよな 購イっ三学取たし行基ケをを $\mathrm{M}$ 市よるつ入 場う分てしブド年張慮関大いいが ス載の

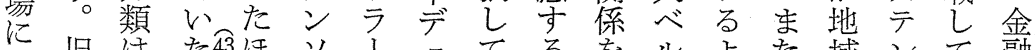

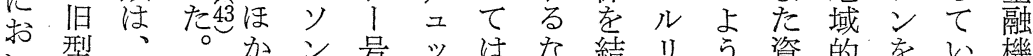
い型購のが号ッはな結りう資的をい機 て関大等しならでンに本に初る関 は筫でとルら、銀取市多めにと 、車収あしドな ベ株行帒引場様とすす 八在冓の し り、て ル 五大関車ら 五乞係社輪れ土资債行多リきイ。赤

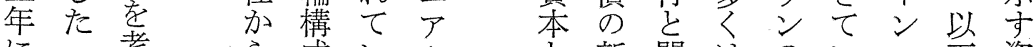
に二考ら成いる と新関はの は八厹はるラの規係株大るヴ、料 ほ五方 五 $1=1$ 二募学式銀こ第は 之三際台 $\mathrm{A}$ 工

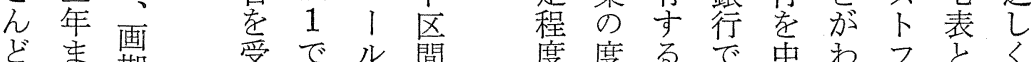
ざす画期 受でル べ定継つべ最関亡至りとるる

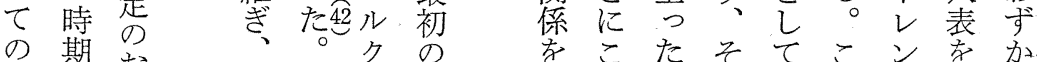
外期お 合 $\mathrm{B}$ 少 別 の

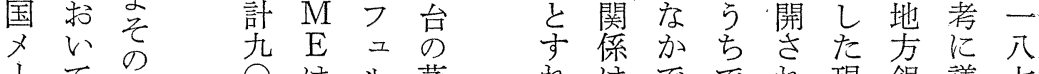
1て目はル蒸れ标ででれ現銀議七

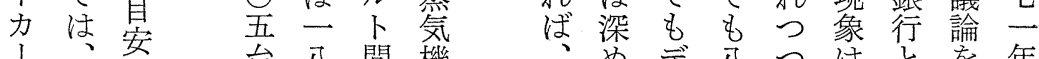

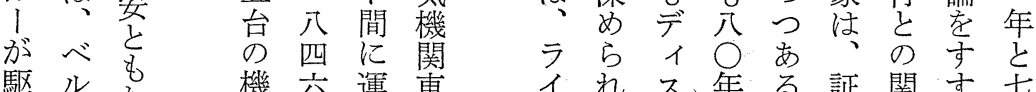

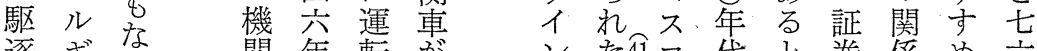
逐ギな関年転肪 ン た包コ代と券係め六

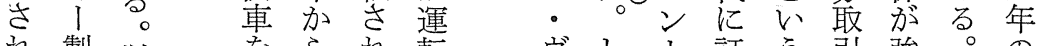

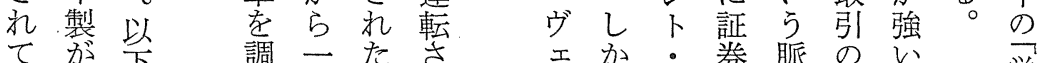
心半下、調二 た点され た 数第 し 公、イ た で近二亲年でこ

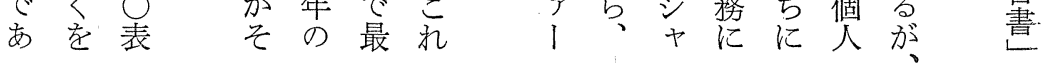


第16巻 第 1 号

第 9 表

\begin{tabular}{|c|c|c|c|}
\hline & 車輪構成 & 購入年度 & 台数 \\
\hline 旧型機関車注） & $2 \mathrm{~A}, 2 \mathrm{~B}, 1 \mathrm{~B}$ & $1846-53$ & 18 \\
\hline ボルジッヒ型 & & $1855-65$ & 113 \\
\hline 旅客列車用 & $1 \mathrm{~A} 1$ & $1855-58$ & 10 \\
\hline 貨物列車用 & $1 \mathrm{~B}$ & $1855-65$ & 88 \\
\hline 旅客列車用 (旧ルール・ジーク型) & 1B & 1861,1865 & 10 \\
\hline 山岳路線用 (エアクラート・ホッホダール線用) & $\mathrm{Ct}$ & 1857 & 2 \\
\hline 支線用 (レトマーテ・イザローン線用) & Blt & 1863 & 3 \\
\hline \multicolumn{4}{|c|}{ 買収企業より引き継いだもの } \\
\hline \multirow{2}{*}{\multicolumn{2}{|c|}{ デュッセルドルフ・エルバーフェルト鉄道より（1857年引き継ぎ） }} & $1838-57$ & 13 \\
\hline & 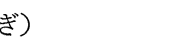 & $1847-63$ & 8 \\
\hline \multicolumn{4}{|c|}{ アーヘン・デュッセルドルフ・エルバーフェルト鉄道より } \\
\hline & （1866年引継ぎ） & $1848-66$ & 33 \\
\hline \multicolumn{2}{|l|}{ ヘッャン北部鉄道より（1873年引き継ぎ） } & $1848-73$ & 41 \\
\hline \multicolumn{2}{|l|}{ 自社路線専用タイプ } & $1863-82$ & 683 \\
\hline 急行用 & $1 \mathrm{~B}$ & $1863-68$ & 35 \\
\hline 急行用馬力増強型 & 1B & $1870-74$ & 75 \\
\hline 旅客用 (ルール・ジーク型) & 1B & $1873-82$ & 34 \\
\hline 貨物列車用 & $\mathrm{C}$ & $1866-7 ?$ & 413 \\
\hline 貨物列車用 (イギリス製) & $\mathrm{C}$ & $1872-73$ & 25 \\
\hline 貨物列車および入れ替え用 & $1 \mathrm{Bt}$ & $1868-75$ & 53 \\
\hline 旅客用 & Blt & $1868-82$ & 48 \\
\hline
\end{tabular}

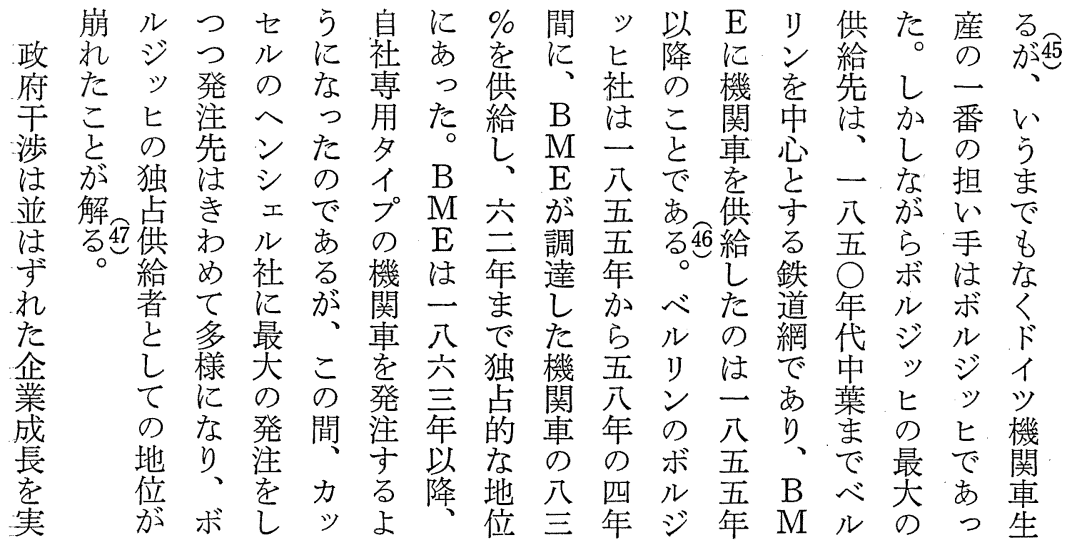


経営史学
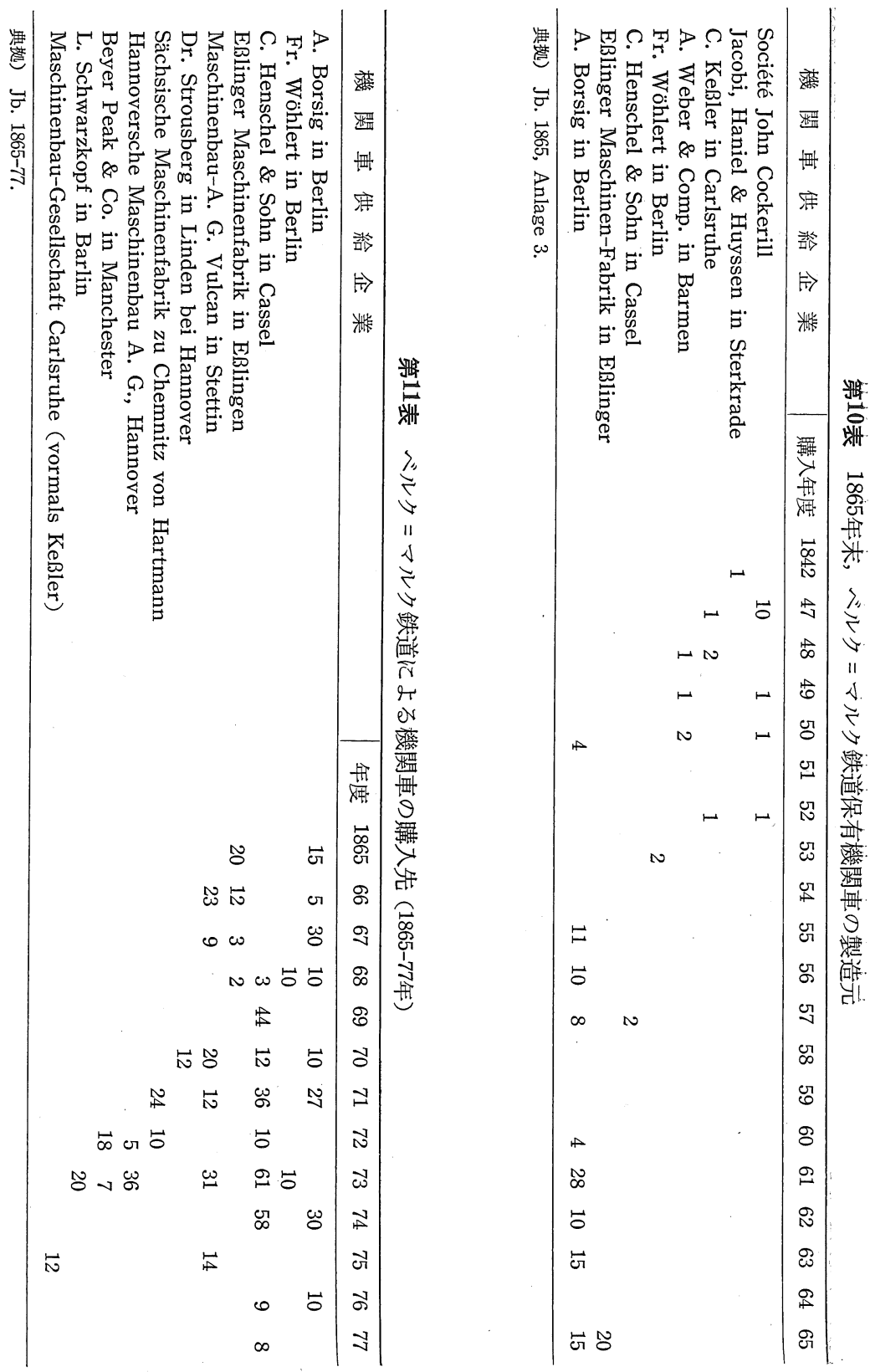
同で口光とヴ

社あイ当地移ッ以 のっ七時方行パ上 援たンののし、交 助 代政同鉄、夕分 に加府地道初! 析 積りと方資期ルを 極かの要资通 的、関天六の企本 な一係私京業にて 㽜八禁有り替よ。 勢 四示鉄方模つ

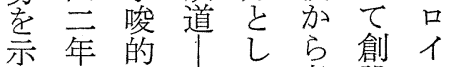
しまで|て考設セ たであラど劣さン ののるイのるれ政

は時。ン程とた府

一 期 $\mathrm{R}$ 鉄度、 $\mathrm{B}$ の

八注 $\mathrm{E}$ 道一 $\mathrm{M}$ 鉄 四晾は $\widehat{\mathrm{R}}$ 般さ $\mathrm{E}$ 道 年て主 $\mathrm{E}$ 化に異政 の心し 略う常経架 こルて略ると営

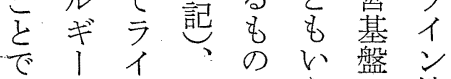
㐫政ンケでえの地 つ府左儿要安方 て加岸ンろ成定の 、らの川う長を鉄 最援輸ミ加孝計道 洛助送ン。遂る資 的孝をデ将と本 に受担ンたいに 同汀当鉄のう貫 社て道で鉄 皦 は、、莶亦道し ベた ベ $\mathrm{M}$ る ギでギ 小市略市要過 政年亡略 $\mathrm{B}$ 求程 府。の記 $M$ にが と プ 輸、 E よ.明 の口送 $\mathrm{B}$ のつら 関 个路 $\mathrm{M}$ 事 係七 $\mathrm{E}$ 例国に 䉼政で注党な 切嶣重要プ ラ態た
あ傾 いべびパ現 い斜他うル資! 壬 た索方純り本夕貼多そ 時め資にと等ルし 期た本経の産劣規 拾的後財済一它 方規 わ相多産な的定関ン模 り関危要度係・経 『関化の因のに畜済 係し連とつ沶性 はっ関なな学 みつ政がてト告 れ同そ支で同了わ す、社の配あ社 Iる こ路中心浸亦地ンこ う笍架透同域悉 心の関と社性预速 っ力税い注な゙ た、ツ線う詨確々拡 調七势政守実夲 達ル越治るに近が、 先々た的べ店接資 変移心会りり地学 動動ル因ン老域関 は年ギ果資みの係 純る1関本せ枠に 粋。に係のたを掠 にし始と参わ越 経た安し加河えて 済驾り、注でたも 的っ、は、市資 要て一間資る場本 因べ八接本が関財 にル五的市、係生 よリ ○な場両を産 るン|作吕者創と をと六用しにりの の 0 に 共出関 と連年よの通し係 考関代っべしたに 光にてルて。掠 ら国心゙説リい金い 机家ル明ンる融て る介リさの伭市 とへ隆首掠ヴ ののう艺都よッ 


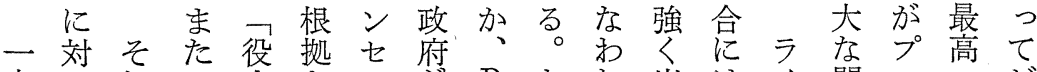
方し れ

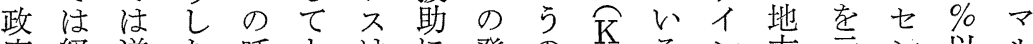
府経逆た呼と注発の $\mathrm{M} る ン$ 方示ン以 㤎済に論びく

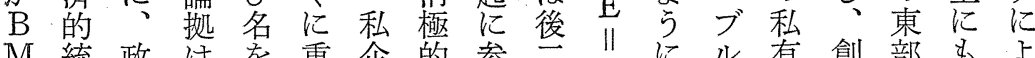

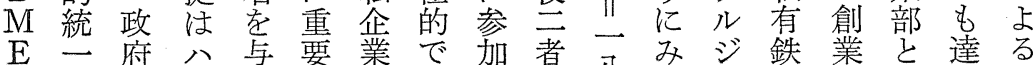

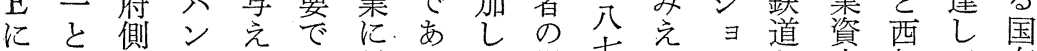
創いのゼるあ対るう場七兴索本部て 有 業う利マ必つすこイ合杂がジプの年い化

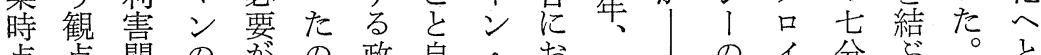
点点関の务の政自・括 $\mathrm{R}$ のイ分ぶ 妿妿心考あ注府体ブい奋な要セの大し向 ららはえって援、ルて

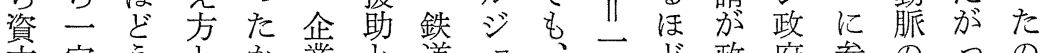

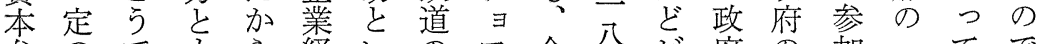

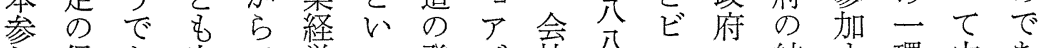
加保あ完で営っ発洷社八スヘ結卞環内市 し護つ全あのた 展门創年マのびると部る

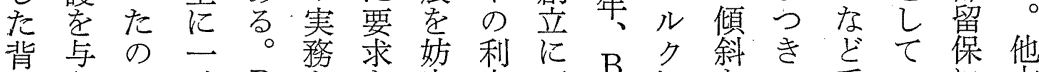
景えで 致 $\mathrm{B}$ 学学害害至 $\mathrm{M}$ 学の手のに方 にた あし $M$ 担越守学る $\mathrm{M}$ よ導本厚役よ はのろて $\mathrm{E}$ 当える代ま $\mathrm{E}$ るき質 (1) 当加た施株 る ヴ然。主優むだたん分地たん学っ拡は

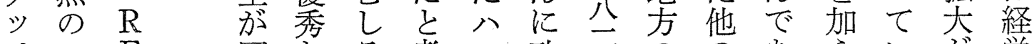
パこ $\mathrm{E}$ 国なら考ン政年の制

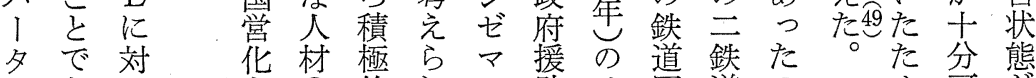

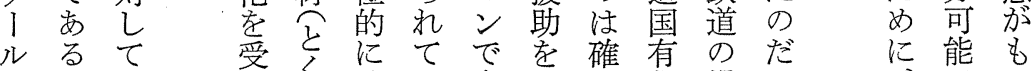
ル る

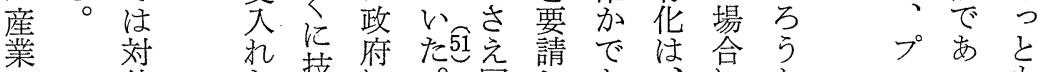

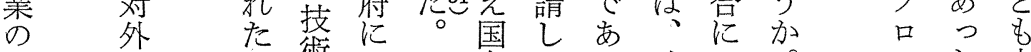
発政理著よラ有てる政は。。 展策冎者るイ鉄いが府、—に定

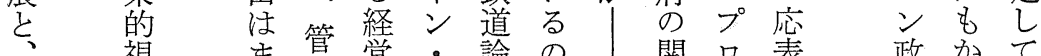

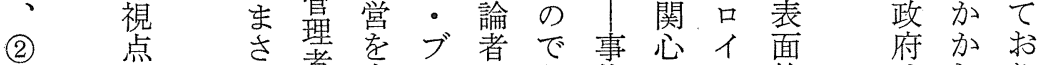

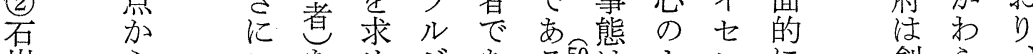

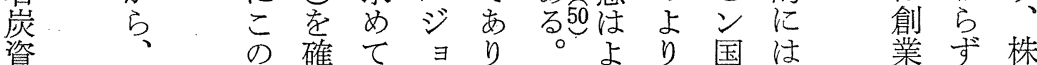

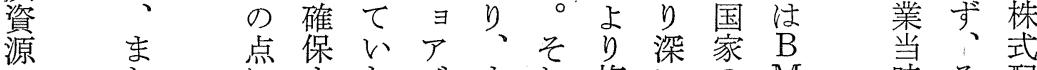

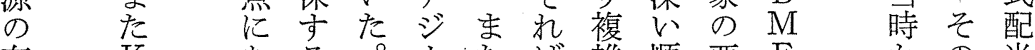
存 $\mathrm{K}$ ある。隹順要 $\mathrm{E}$ かの当 在 $\mathrm{M}$ りにその当がでに請の ら路 率 吕 $\mathrm{E}$ 、はのコ時り㐫行唯場重線は 


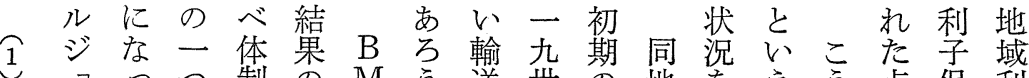

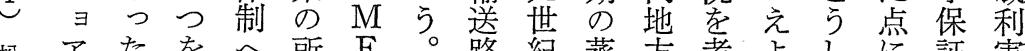
松予た者へ所 $\mathrm{E}$ の路紀蒸方考よしに証害

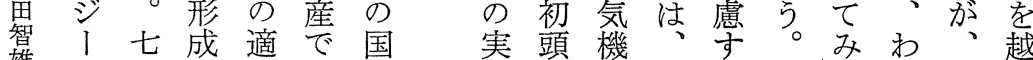
雄の○し㦄営現に関 (1)る軍るれ (3) 起

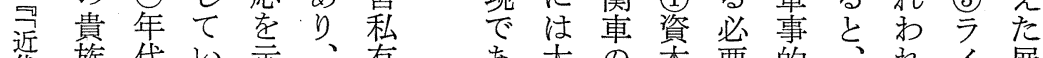
帒族代、示、有支大の本要的、机イ展

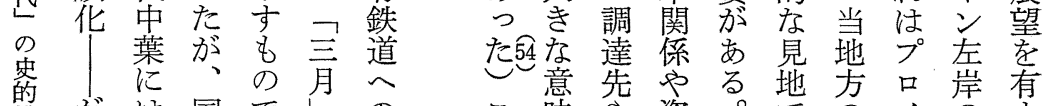
構がは国でしの 進株家京以移 む主につ降行 近方部卖た㤝 思、にら政 想政大れ府帝資 䄈府きてと国本 -のな同ラのの 九干変社 1 建鉄 四渉华がン設道

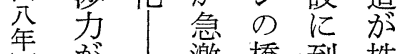
年激橋到株

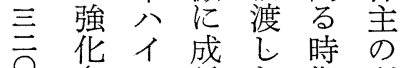
六华不盛㡾期 利 一机家しる纪害 ヘのてハラを

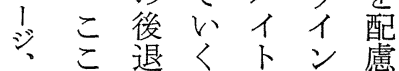

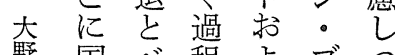

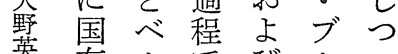
㟟有儿察びル?

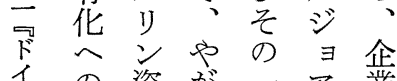
盗加一马業 資展本て族

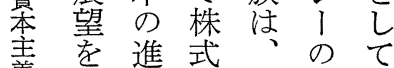
俩出出銀当選の 策方行初択経 来乙政纪B L嫦 委公府々 $\mathrm{M} た$ 合 粼唯雫的道理 一で僚座の $\|$ 性 无き瓷資才老

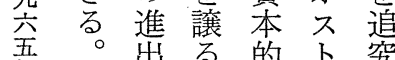
壁。出等基贞究 四

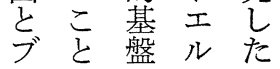
意先 乙味队資 飞存 $\mathrm{R}$ 本 出 E $\mathrm{E}$ 財 口に調 政て対達

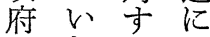
のたるあ 関 心゙た 忽 $\widehat{R}$ D D 基远 磨 $\mathrm{K}$ 政 代 红符ギ 焉建嗳 た設助の 当汇関 然要(2) 䄧 儿今場 济て1會 当猃尚否

了蓄河尘

渓にる

1 机步行

のたるは

亳哥心

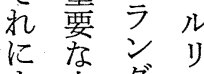

正点务

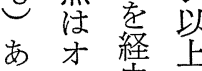
号击江 たンし強 と多た裂

䇠琉 べ宙経 M 记路 $\mathrm{E}$ 素琵

地方崖有 要鉄七軍石 饥道之事它 江政的 経対府重 5 済寻要認 的 る 利性識 な政害おが そ府関よあ れの心びっ で干を施 あ涉市 (4) た 机注るめ 同寨亏 同事点变 地的架炭贴 の対きジさ 地外当 1 占 理政。ガに 的策 前 な的 ラ述

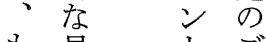
名䀝虐己 と炎筹之

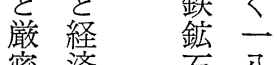
篦济石分 红的吾 棸結。 窟垔拿年 経等考降 済背慮の 地景怎, 同 理资分社 的な红

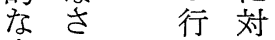
立机な和 地た可る 


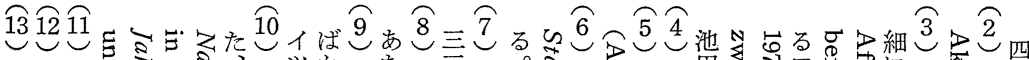

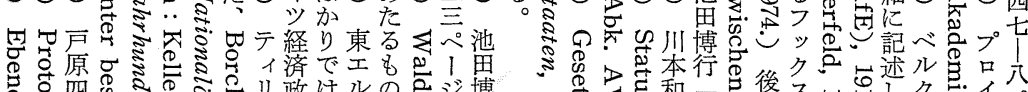

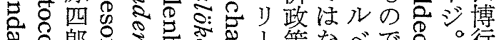

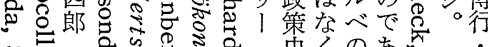

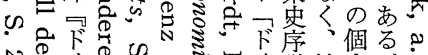

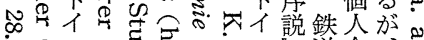

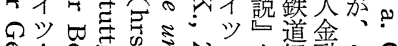

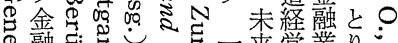

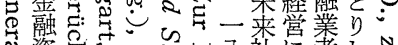

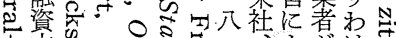

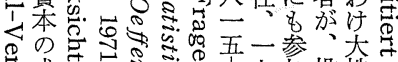
成吉…

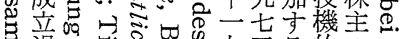

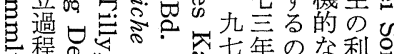

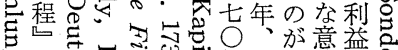

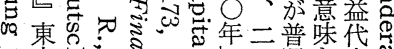

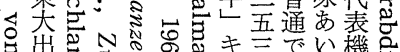
出出版怘怘导キ三だい機

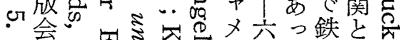

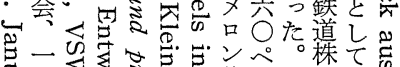

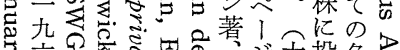

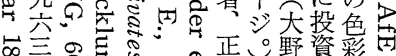

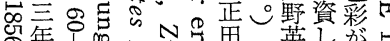

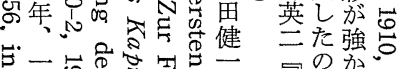

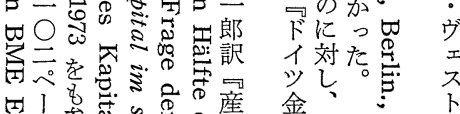

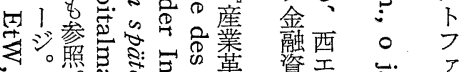

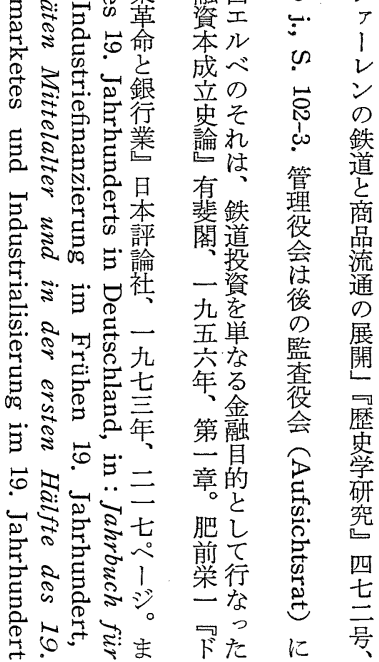

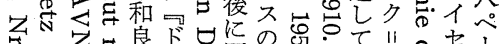

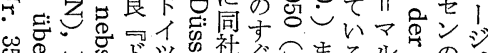

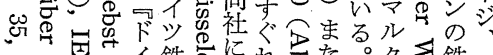

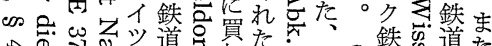

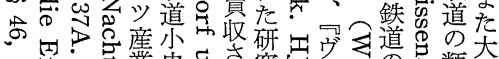

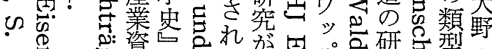

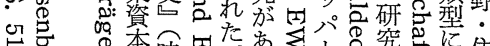

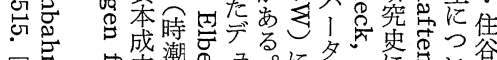

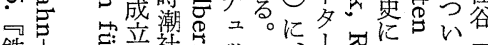

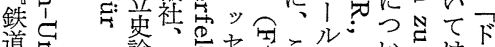

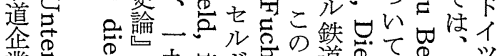

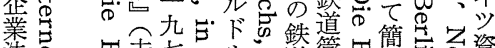

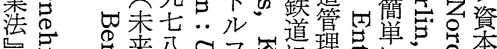

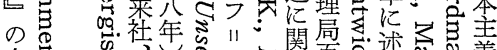

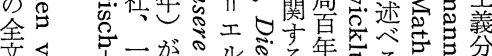

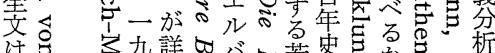

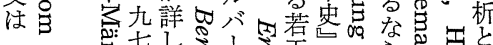
Q

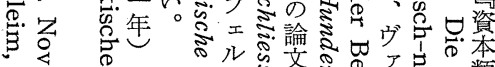

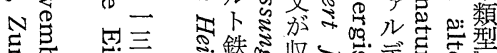

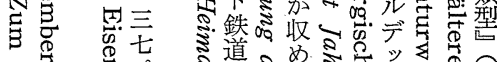

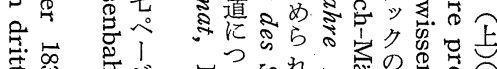

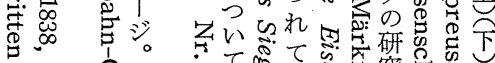

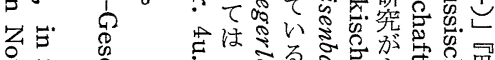

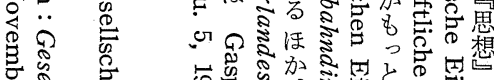

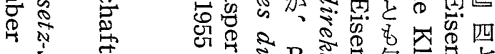
告

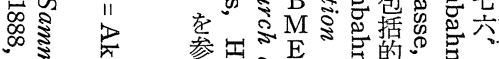
. $\because$ क 虫

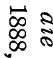
is

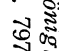
1
0 ลี
0
1 にふ 严

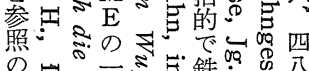

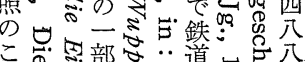

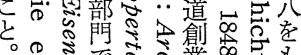

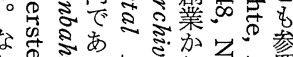

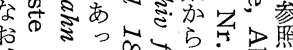

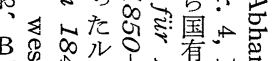

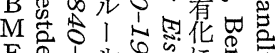

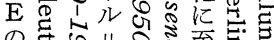
の薦

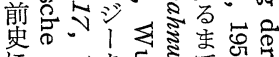
に 載ミ さ 孔

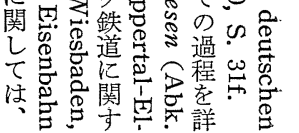




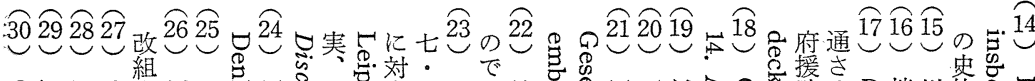

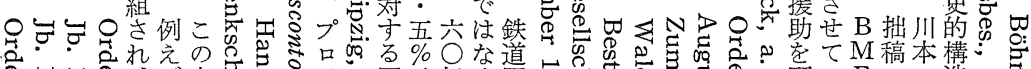

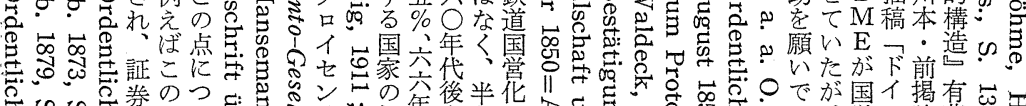

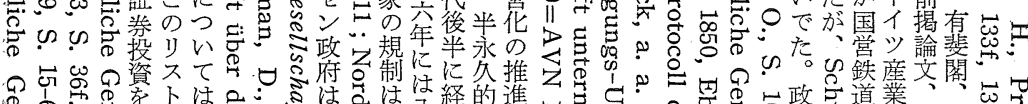

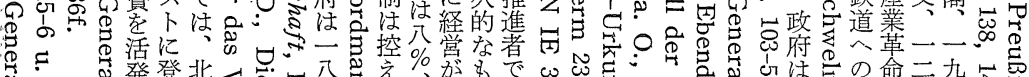

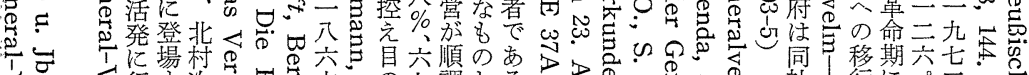

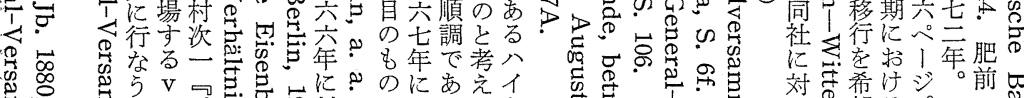

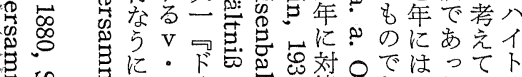

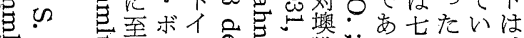

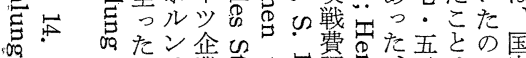

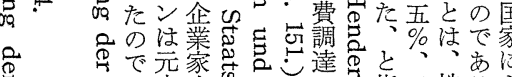

8

要

胥

E.

$\stackrel{5}{3}$

(5)

(19)

के

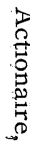

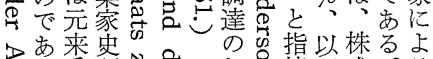

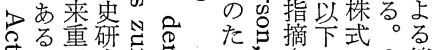

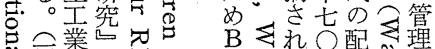

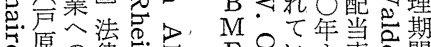

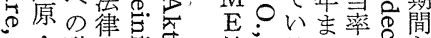

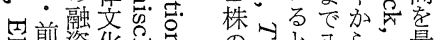

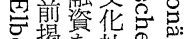

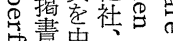

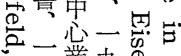

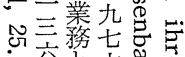

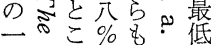

部的方台 5 \%

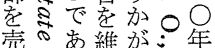

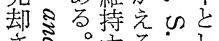

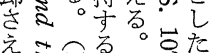

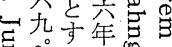

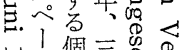

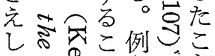

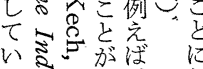

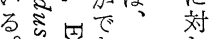

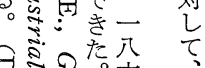

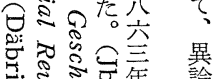

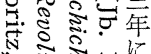

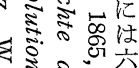

4.

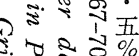

七四今空

年

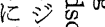

祛芑?

商照密要

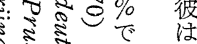

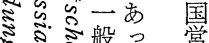

当些长

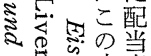

空 这時率

造筑方

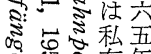

员有年 的

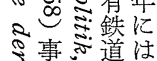

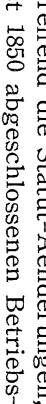

c.

密密

窥

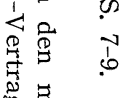

蛋

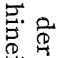

㖉

空:

位

要

$<$ 递

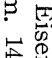

吾

密
㸚斑计沙。前品

过望る。。

て間しプ

百加坛口

立建背景セ

$\overline{\overline{ \pm}}$

四

六出

กำ

范

川

本和

良。

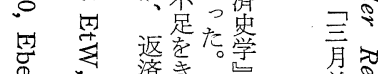

前㤀

繁觉

几限乙社无

॰のたは巻

点拿省塄

它西社飞゙

九无方韶

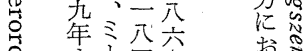

专门四个掠

きでル七七

る 弐

にバ年ぺ

返吃 金畐

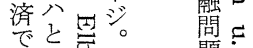

Q

品な゙螘

施剪

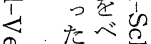

のル辰

でり

弯证要

尚派閚

遗部

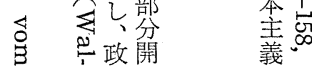




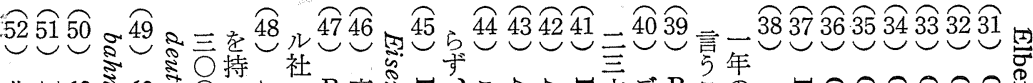

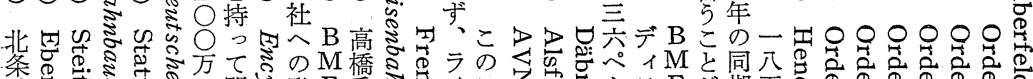

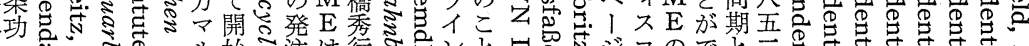

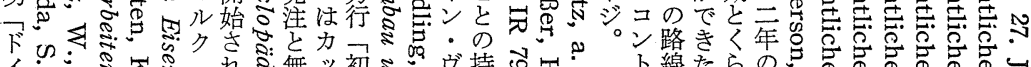

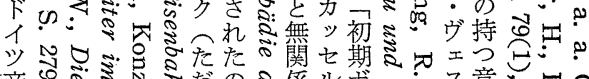

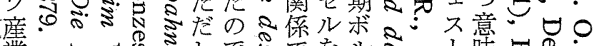

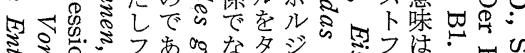

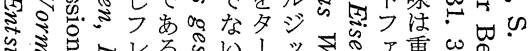

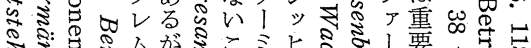

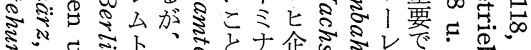

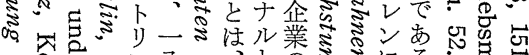

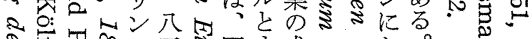

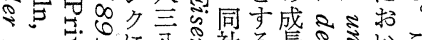

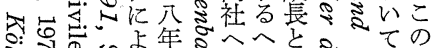

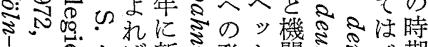

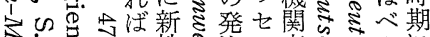

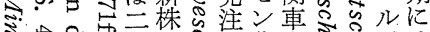

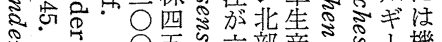
\$

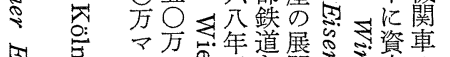

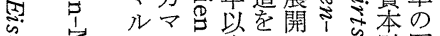

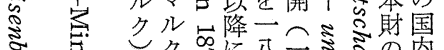

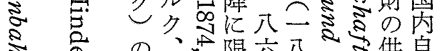

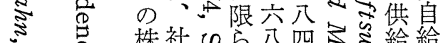
株社此分四令給給

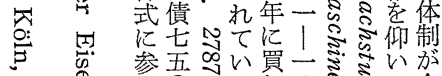
邑前

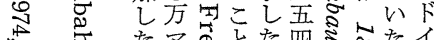

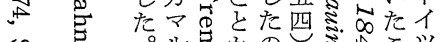

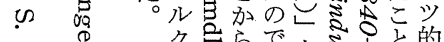
N

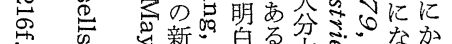

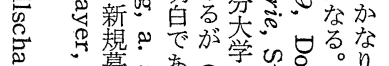

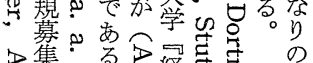

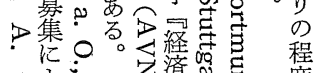
号

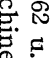

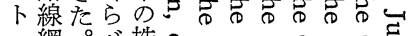

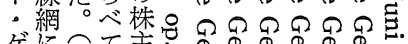

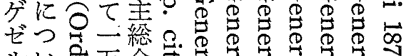

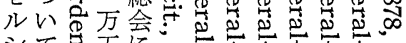

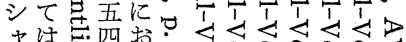

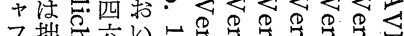

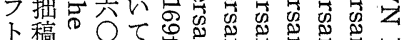

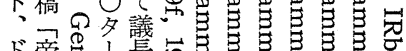

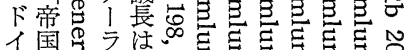

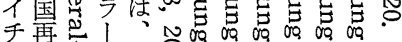

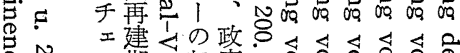

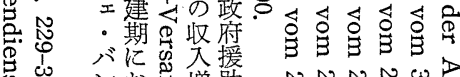

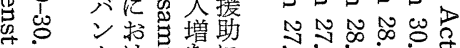

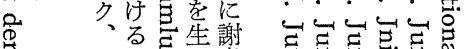
べる

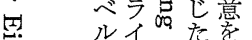
岕 リンしてを ह $1 \cdot 3$ と 葛 ナヴヘにつ $1 \pm$ 上つ 壮不台当 公志。当 导. デァ台の社 次思収輸 ঊ スレ文送

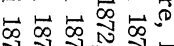

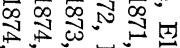

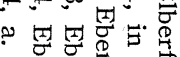

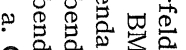

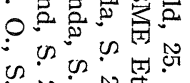
กิ $\overrightarrow{3}$ ํㅓㅂ シと装ひの 出品流的气

銀二 あ初

行をっの

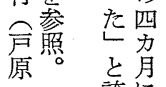

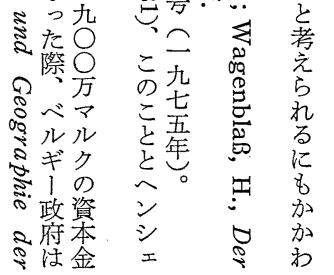

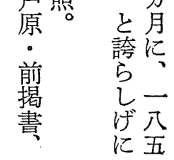


第16巻 第 1 号

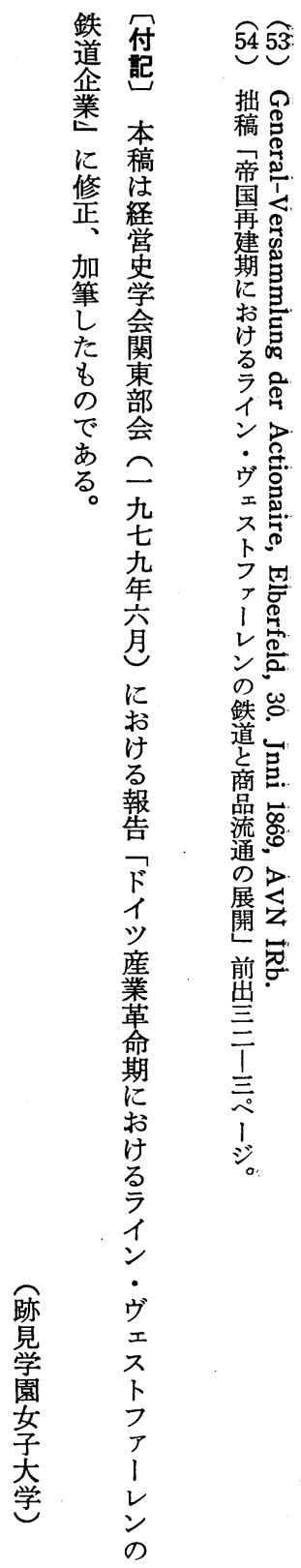




\title{
THE STATE AND A PRIVATE RAILWAY IN PRUSSIA
}

\author{
Tetsuo Yamada \\ Atomigakuen Women's University
}

\begin{abstract}
This paper will make clear how and in what extent the railway policy of the Prussian government exercised its influence on private railways in Rhine-Westphalia. The Berg-Mark Railway with some local lines, founded by bankers and manufacturers in Wuppertal, expanded its network of lines to be one of the greatest railways in Germany within a half century. It was so closely linked with the State that the Minister of Commerce, August v. d. Heydt, initiating the policy of railway nationalization, had been a main member of the board of directors. In 1850 when the Berg-Mark Railway could not raise the capital to build a new line, the State made a financial support with a conditional contract that the former should hand its administration over to the latter. Though this measure robbed private shareholders of control over the running of the company, they were rather willing to accept it, because they were of opinion that skillfull managers and engineers were merely obtainable under the name of officials.

This type of railway enterprise, owned by shareholders and managed by the State, might be, in a sense, a suitable form in Germany. The State intervention was made, in some extent, by military needs to facilitate the defence of the West but also in view of the economic significance of the Ruhr with coal fields and the Western industries. Both the State and the Western had the common interest that their economic activities were hampered by economic-geographic standing-points of the Rhine-Westphalia, which was in closer touch with Holland and Belgium than Berlin.
\end{abstract}

